\title{
Palaeofluid evolution in a fractured basalt hosted reservoir in the Üllés-Ruzsa-Bordány area, southern sector of the Pannonian Basin
}

\author{
Barbara Szabó ${ }^{1,2}$, Félix Schubert ${ }^{2}$, Tivadar M. Tóth² and Gábor Steinbach ${ }^{3,4}$ \\ ${ }^{1}$ Exploration and Production, MOL Plc., Budapest, Hungary \\ 2 University of Szeged, Department of Mineralogy, Geochemistry and Petrology, H-6701 Szeged, P. O. Box 651, Hungary; (barbokster@gmail.com) \\ ${ }^{3}$ Biological Research Centre, Szeged, Hungary \\ ${ }^{4}$ CAS, Centrum Algatech, Institute of Microbiology, Třeboň, Czech Republic
}

doi: $10.4154 / g c .2016 .25$

\section{Article history:}

Manuscript received May 19, 2015 Revised manuscript accepted August 22, 2016 Available online October 07, 2016
Keywords: fractured basalt reservoir, Pannonian Basin, zeolite minerals, hydrocarbon-bearing fluid inclusion, fluorescence

\begin{abstract}
Extensive Miocene volcanic activity produced basaltic and pyroclastic successions, which were penetrated by many wells in the area of Üllés-Ruzsa-Bordány, in the western and central part of the Great Hungarian Plain. The Kecel Basalt comprises primary porosity from a high proportion of vesicles and significant secondary fracture porosity, as well. Due to the significant fracture porosity, some depth intervals show good reservoir characteristics, although the fractures crosscutting the rock body are partly or entirely cemented by various minerals. Based on the textural and mineralogical features, four distinct vein types can be distinguished, named after their volumetrically most abundant cement phases, i.e. potassium-feldspar (Kfp-), calcite (Cal-), laumontite (Lmt-) and analcime (Anl-) types. This study focuses on probably the youngest of these vein types, the Anl-type. Based on the study of veins and mineral sequences, the direction of temperature changes cannot be given unequivocally for every stage of cementation, but crystallization of the Anl-type veins might have occurred at lower temperatures than the formation of the Lmt-type veins. Fluid inclusion studies suggest that hydrocarbon migration and accumulation took place after cementation of the first three vein types (Kfp-, Cal- and Lmt-types). In the newly opened fracture system, two types of hydrocarbon ( $\mathrm{HC} 1$ and $\mathrm{HC} 2)$-bearing fluid inclusion assemblages were captured during precipitation of analcime and later zeolites. This refers to two stages of hydrocarbon migration in the fracture system. Observations of the fluorescence colours and low temperature behaviours of the hydrocarbon-bearing inclusions, the earlier HC1 petroleum-inclusions captured heavier (presumably less mature oils), while the later ones (HC2) lighter (presumably more mature) oils. The $\mathrm{HC} 2$ petroleum seems to be very similar to the crude oil sampled in a well in the area based on their fluorescence parameters.
\end{abstract}

\section{INTRODUCTION}

Volcanic rock bodies, which reserve economically important amounts of hydrocarbon, are rather uncommon worldwide (e.g. Farooqui et al., 2009). The Üllés-Ruzsa-Bordány area in SW Hungary is one of these; the reservoir consists of monotonous basalt and its pyroclastic varieties (Kecel Basalt Formation $\mathrm{KBF}$ ), approximately $200 \mathrm{~m}$ thickness. Early studies support detailed petrographic results on KBF focusing exclusively on the highly altered host rock itself (CSEREPESNÉ, 1978; PAP, 1983; BALÁZS \& NUSSZER, 1987). Today, important aspects concerning the reservoir characteristics are also studied (SZABÓ et al., 2009a, b, 2012)

Due to the dense fracture network and the significant fracture porosity, some depth intervals of the igneous body show good reservoir characteristics. These fractures are partially or entirely cemented by various minerals making examination of their fluid inclusions and so principles of ancient fluid migration events possible. Four distinct vein types can be distinguished based on textural and mineralogical features. Named after their volumetrically most abundant cement phases, these are the potassium-feldspar (Kfp-), calcite (Cal-), laumontite (Lmt-) and the analcime (Anl-) types, respectively. A summary of the characteristics of all these vein types was published in SZABÓ et al. (2009a), while the detailed description and circumstances of the evolution of the first three types were discussed by SZABÓ et al. (2009b). Nevertheless, from a petroleum geology point of view, the most important vein generation is the youngest one, since hydrocarbon inclusions were identified exclusively in its vein filling mineral phases (SZABÓ et al., 2009a). It was previously proven (SZABÓ et al., 2009a) that rocks of the KBF are characterized by two types of porosity comprising an extended fracture system and partially-filled vesicles.The occurrence of similar petroleum inclusions both in the cemented Anl-veins and in the adjacent wall-rock vesicles suggests that filling of the reservoir took place not only along localized fractures but also along altered basaltic zones around them. The evolution of the youngest vein generation and its role in the hydrocarbon system in question is the focus of the present paper. The key questions concern the subsidence history of the area through estimating temperature and pressure change during the formation of the reservoir, as well as the stages and the timing of petroleum migration. Utilising geochemical data, SZABÓ et al. (2012) evidenced a genetic relationship between the potential source rock (marl) and the hydrocarbons produced. From this aspect the area in question is a hydrocarbon system based on the definition of MAGOON (2004).

The study of the vein-filling minerals and their fluid inclusion assemblages could provide valuable information about the post-volcanic evolution of the area, the circumstances of hydro- 
carbon migration and the accumulation processes in a hydrocarbon system (e.g. KARLSEN et al., 1993; GEORGE et al., 1997; BOURDET et al., 2010). In addition, the evolution of reservoir charging can further be specified by the methods of PIRONON et al. (1998) or APLIN et al. (1999), who used the systematic change in homogenization temperature $\left(T_{\mathrm{h}}\right)$ and vapour volume fraction $\left(\varphi_{\text {vap }}\right)$ values of petroleum inclusions in order to estimate the pressure of hydrocarbon migration. Hereafter the vapour volume fraction is defined as the proportion of vapour volume and the amount of vapour and liquid volume $\left(\varphi_{\mathrm{vap}}=V_{\mathrm{vap}} /\left(V_{\mathrm{vap}}+V_{\text {liq }}\right)\right)$.

Considering different thermometric data of all subsequent vein types, the post-volcanic temperature evolution and the subsidence history of the volcanic rocks could be modelled in the study area. Data gained from fluid inclusion analyses could provide further contributions to our present knowledge regarding the stages and timing of petroleum migration.

\section{GEOLOGICAL SETTING}

Several wells were drilled in the Late Miocene basaltic rocks of the KBF in the central and SW part of the Great Hungarian Plain, in the area of Szank, Kiskunhalas, Sándorfalva, Pusztamérges, Üllés, Ruzsa and Bordány (Fig. 1) (CSEREPESNÉ, 1978; PAP, 1983; BALÁZS \& NUSSZER, 1987). The formation consists of pyroclastic and lava rocks interbedded with up to several hundred meter thick layers of the Endröd Marl Formation (EMF). The Endröd Marl is regarded as one of the most important source rocks in the area, although in many areas its thermal maturity is highly variable and the results of the oil-source correlations are not unequivocal (e.g. BADICS et al., 2011; BADICS \& VETÖ, 2012 and references therein). The lithofacies of the Endrőd Marl varies from calcareous to argillaceous marls, depending on palaeo water depth and other depositional conditions in the Lake Pannon (MAGYAR et al., 1999). The Tótkomlós Calcareous Marl Member of the EMF includes fossils (e.g. Congeria cžjžeki M. HÖRN., Congeria sp., Limnocardium abichi R. HOERN. var., L. cfr. abichi R. HOERN., L. desertum STOL., L. cf. desertum STOL., L. triangul costatum MAL., Limnocarcium sp., Amplocypris sp., Candona (Pontoniella) acuminata ZALÁNYI, C. (bacunella) sp., C. (Camptocypria) sp., etc.) (BALÁZS \& NUSSZER, 1987). Based on biostratigraphic evidence the age of the calcareous marl underlying the pyroclastic rocks in the Üllés-22 well is between 8.1-10.8 Ma years (MAGYAR et al., 2004). These results are in agreement with the whole rock K/Ar radiometric ages of the volcanic rocks, determined as $8.13 \pm 0.71 \mathrm{Ma}$ from Kecel-1, as 9.61 \pm 0.38 Ma from Kiskunhalas-Ny-3 and as $10.4 \pm 1.8$ Ma from the Ruzsa-4 wells (CSEREPESNÉ, 1978; PAP, 1983; BALÁZS \& NUSSZER, 1987).

The KBF has been explored in almost 30 wells in the areas of Üllés, Ruzsa and Bordány (Fig. 1). The volcanic rocks were penetrated between 2200 and $2900 \mathrm{~m}$ with a maximum thickness of $185 \mathrm{~m}$. These basaltic rocks show intense chloritization and carbonatization as the result of metasomatism following the subaqueous volcanism (SZABÓ et al., 2009b). Fractures are often cemented by minerals (prehnite, chlorite, quartz, calcite), in particular by different zeolites (laumontite, thomsonite, analcime, mesolite, heulandite, stilbite). Four distinct vein types can be dis-
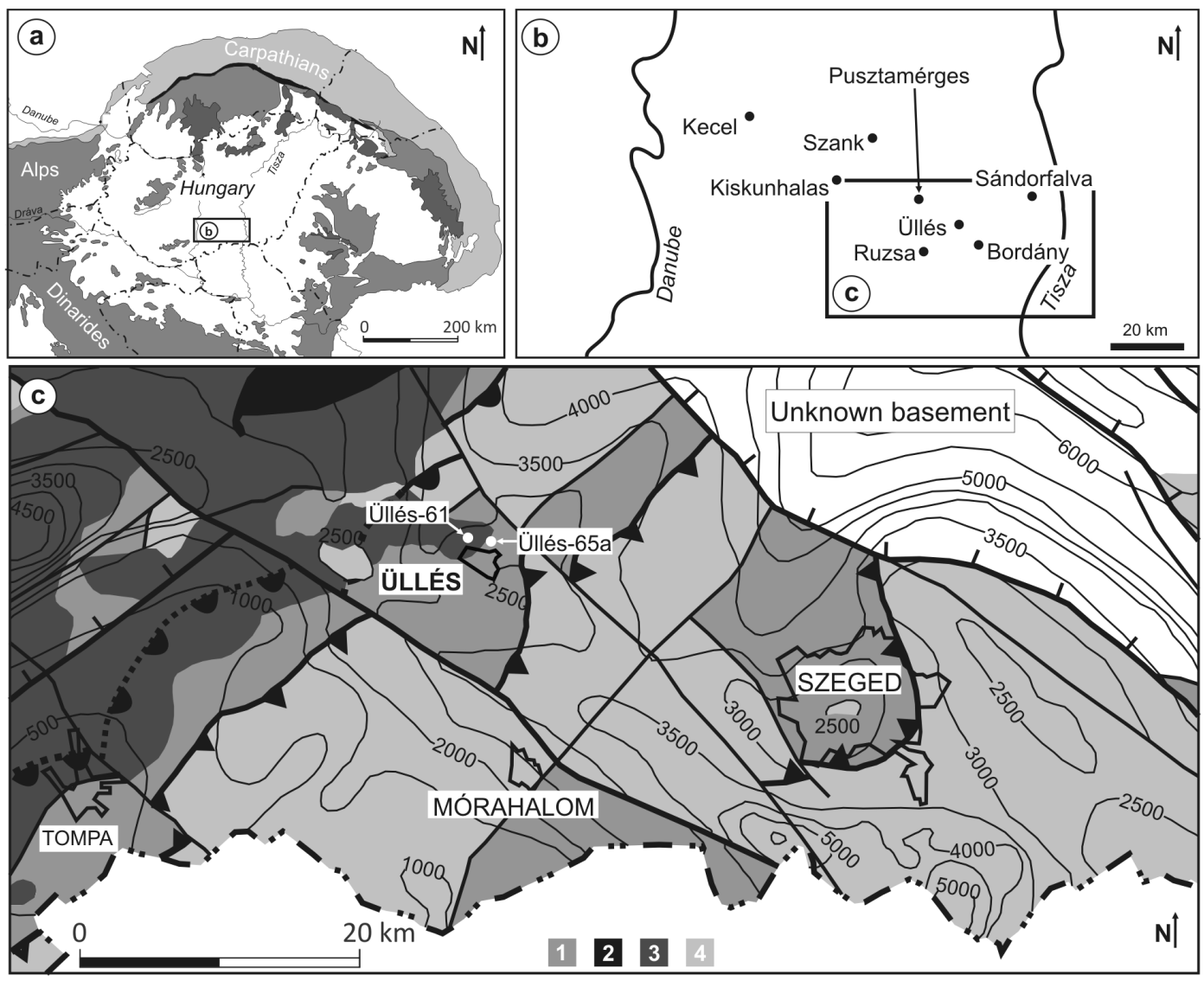

Figure 1. a) Occurrence of the Kecel Basalt Formation within the central Pannonian Basin of Hungary. b) Location of settlements in the vicinity of which rocks of the Kecel Basalt Formation were reported from drillcores. c) A detailed sub-surface topographic and geological map of the study area. Contours show depth (m) to pre-Cenozoic basement. White dots mark wells (labelled Üllés-) from which hydrocarbon-bearing analcime grains were investigated in this study (modified after HAAS et al., 2010). 1. Middle Triassic shallow marine siliciclastic and carbonate rocks. 2. Lower-Triassic siliciclastic rocks of fluvial and delta facies. 3. Jurassic and Cretaceous rocks. 4. Pre-Mesozoic basement. 
Table 1. The basic parameters of the occurring vein types.

\begin{tabular}{|c|c|c|c|c|}
\hline & Kfp-type & Cal-type & Lmt-type & Anl-type \\
\hline Host rock & lapillis & basalt & basalt and pyroclast & basalt and pyroclast \\
\hline Occurrence & Ruzsa-21, Üllés-61 & Bordány-2, Üllés-77 & Ruzsa and Üllés area (except for: Üllés-61) & Üllés-61, Üllés-65/A (in cuttings) \\
\hline Vein microstructure & syntaxial & antitaxial & syntaxial (ataxial) & syntaxial \\
\hline Cement minerals & $\begin{array}{l}\text { K-feldspar } \\
\text { Quartz } \\
\text { Albite } \\
\text { Laumontite } \\
\text { Calcite }\end{array}$ & $\begin{array}{c}\text { Weathered } \\
\text { volcanic material } \\
\text { Calcite } \\
\text { Heulandite }\end{array}$ & $\begin{array}{c}\text { Prehnite } \\
\text { Chlorite } \\
\text { Laumontite } \\
\text { Thomsonite } \\
\text { Calcite }\end{array}$ & $\begin{array}{l}\text { Analcime } \\
\text { Mesolite } \\
\text { Heulandite } \\
\text { Stilbite }\end{array}$ \\
\hline
\end{tabular}

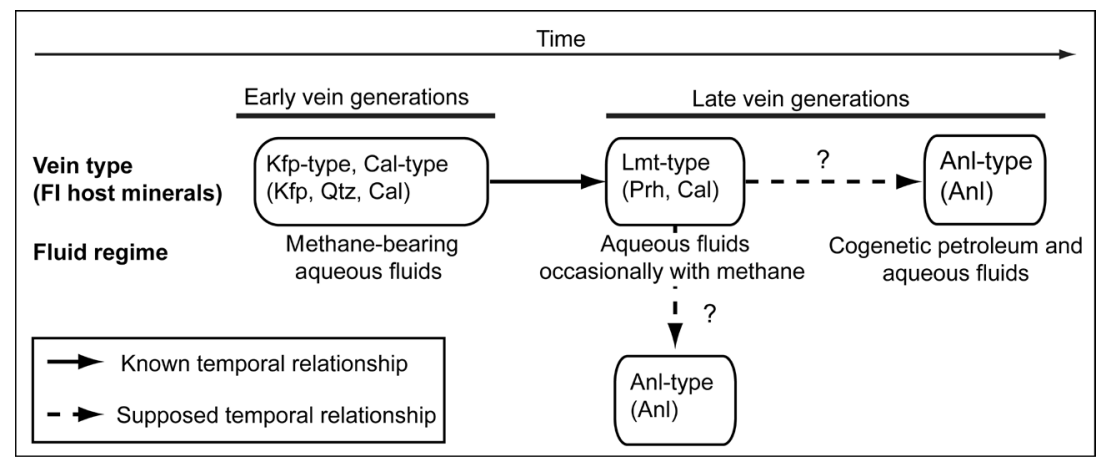

Figure 2. Paragenetic diagram of fracture-hosted minerals indicating the reigning fluid regime during their precipitation. Based on cross-cutting relationships the age of Anl-type veins relative to the Lmt-type ones cannot be determined unequivocally, hence, we have marked both of the feasible scenarios on the diagram.

tinguished based on their mineral compositions and the textural relationships of the mineral sequences in the veins (Table 1; Fig.2).

The veins of the earliest K-feldspar (Kfp)-type could only be observed in lapillis and contain potassium feldspar, quartz, albite, laumontite and calcite (Table 1). The basalt hosted Calcite (Cal)type veins are filled by altered volcanic material in the central part, and calcite and heulandite along the vein walls (Table 1). These types formed prior to significant diagenetic alteration of the pyroclastic material. The Laumontite (Lmt)-type veins formed later, during formation of the early fracture network and are composed of the prehnite-laumontite-thomsonite-laumontitechlorite-calcite mineral sequence. Details on the fracture fillings of the first three of the four vein types were given in SZABÓ et al. (2009b).

Fluid inclusion microthermometry was performed on twophase $(\mathrm{L}+\mathrm{V})$ fluid inclusions in fracture-filling minerals with a well-defined position in the mineral sequence (Table 1). In Kfptype veins, the two-phased $(\mathrm{L}+\mathrm{V})$ aqueous inclusions in the Kfeldspar, quartz and calcite crystals contain methane in the vapour phase at room temperature. In Lmt-type veins, the primary inclusions in the prehnite contain methane in the vapour phase at room temperature, but the rare single two-phase aqueous inclusions in calcite with no identifiable genetics do not contain any methane. For the fluid inclusion petrography and microthermometry of the first three vein types (Kfp-, Cal- and Lmt-types) see SZABÓ et al. (2009b).

Post-volcanic temperature changes during their cementation were reconstructed for the first three types of veins (Kfp-, Cal- and Lmt- types), based on their study andthermo-baromet- ric models, (SZABÓ et al., 2009b):The minerals of the Kfp-type veins precipitated in fractured lapilli before the final consolidation of the volcanic sediment at around $140-155^{\circ} \mathrm{C}$. The calcite of Cal-type veins crystallised in the fractures of basalt after it was partially filled by altered volcanic material. The earliest cement phases in the Lmt-type veins from prehnite to thomsonite clearly suggest a cooling trend during fracture cementation from around $130-180{ }^{\circ} \mathrm{C}$ to $50-90{ }^{\circ} \mathrm{C}$. However, in the next phase, Lmt veins suggest an increasing temperature for their late evolution $\left(150-225^{\circ} \mathrm{C}\right)$ on the basis of the temperature stability of laumontite.

\section{SAMPLES AND METHODS}

For petrological and analytical studies, core samples and cuttings from the collection of the MOL Hungarian Oil and Gas Plc. were used. The cores of the Üllés-61 well and cuttings from the Üllés65/A well were chosen for further investigation as being representative of the fracture cementation of the Anl-type veins and also because they exhibit traces of hydrocarbon migration (Fig. 1). The crude oil was sampled from the well head of Üllés-61 (Table 2).

Prior to macroscopic observations, the samples were carefully cleaned by water and in some cases in an ultrasonic bath. The macroscopic observations were carried out to explore the main characteristics of the fractures, the paragenesis and spatial relationships of the fracture-filling minerals. The petrographic investigation of the host rock and fracture cement was performed on cores, cuttings and thin sections using Olympus SZX7 binocular and Olympus BX41 polarization microscopes. Raman microspectroscopy, fluid inclusion petrography and microthermometry

Table 2. The samples from the study area.

\begin{tabular}{|c|c|c|c|c|c|}
\hline Well & $\begin{array}{l}\text { Kecel Basalt Formation } \\
\text { (MD in } \mathrm{m})\end{array}$ & $\begin{array}{l}\text { Depth of sample } \\
\text { (MD m) }\end{array}$ & Type of sample & Rock type & Fracture-filling minerals \\
\hline \multirow{2}{*}{ Ü-61 } & \multirow{2}{*}{$2235-2405$} & $2238-2250$ & Core & basalt, basalt agglomerate & K-feldspar, chlorite, calcite, analcime, mesolite, heulandite, stilbite \\
\hline & & $2329-2340$ & Crude oil & - & - \\
\hline Ü-65/A & $2198-2340$ & $2264-2330$ & Cuttings & basalt, basalt agglomerate & prehnite, chlorite, laumontite, analcime, heulandite \\
\hline
\end{tabular}


were performed on thick sections prepared from core samples (6 sections) and cuttings ( 3 sections) at the Department of Mineralogy, Geochemistry and Petrology, University of Szeged. Prior to the analytical procedures and microscopic observations, thin sections $(30-50 \mu \mathrm{m})$ and double-polished thick sections $(75-150 \mu \mathrm{m})$ were prepared from the cores and cuttings. If it was necessary, the samples were impregnated with epoxy resin under vacuum at $40{ }^{\circ} \mathrm{C}$ for at least 24 hours, and then cut into pieces by a Buehler IsoMet low speed saw. The surfaces were ground and polished using $\mathrm{SiC}$ and diamond sprays. During the sample preparation the methods of SHEPHERD et al. (1985) were followed.

Raman spectra of fracture-filling minerals and fluid inclusions were recorded in part with a Horiba JobinYvone spectrometer connected with an Olympus BX40 microscope (Budapest University of Technology and Economics), and with a Labramtype spectrometer connected to an Olympus U-D6RE microscope (University of Nantes) using 50X and 100X LWD objectives and in accordance with the methods of BRUKE(1994). The radiating laser source operated at $532 \mathrm{~nm}$ in the former and at 488 $\mathrm{nm}$ in the latter case. The acquisition time was chosen depending on the intensity of the signal, usually $10-30$ seconds in the case of minerals and 60-100 seconds in the case of fluid inclusions, accumulated 3-5 times.

Fluid inclusion petrography was performed on fracture-filling minerals of rock samples with a well-defined position in the mineral sequence. The observations were made using an Olympus BX41 polarization microscope in normal and in ultraviolet light following the methods of GOLDSTEIN (2003). Based on the petrographic evaluation of the thick sections, UV fluorescent micro-spectroscopic measurements were carried out to identify the different petroleum inclusion assemblages. For this purpose a PARISSH Spectral Imaging System (Lightform Inc., Hillsborough, NJ, USA) mounted on an Olympus IX71 inverted research microscope was used to collect the fluorescence spectra. The light from a selected line of the microscope's field of view is wavelength dispersed by the spectrometer and focused on a Peltiercooled charge coupled device. The recorded image consists of intensity values with their spatial and wavelength coordinates. The spectral imaging system provides simultaneously several full spectra uniformly distributed along a conveniently selected spatial direction. In these investigations the observation line (projection of the entrance slit) was chosen to be through the entire inclusion. During the detection an Olympus U-MNU2 filter cube (excitation filter $-360-370 \mathrm{~nm}$, emission filter -420 , dichromatic mirror $-400 \mathrm{~nm}$ ) was used. About 100 spectra were measured and data collected on each petroleum inclusion. To optimize the signal-to-noise ratios, the spectrum of the highest intensity from among the collected spectra of the single petroleum inclusions was chosen. The UV fluorescent parameters of the crude oil sample were also measured by this equipment. For this a drop of the oil was put on a glass slice and it was covered by a quartz coverslip. To facilitate comparison between different inclusion generations, each spectrum was transformed into coordinates that can be plotted in the CIE-1931 chromaticity diagram. This transformation (e.g. WYSZECKI \& STILES, 2000) involved multiplication of the spectrum independently by three colour-matching functions, which describe the non-linear perception of the human eye to red, green and blue hues. Integration of the three product functions over the acquired spectral range ( 400 to $880 \mathrm{~nm}$ ) yields three so-called tristimulus parameters. Their sum is the perceived colour according to the CIE-1931 convention. The fraction of each parameter with respect to the sum corresponds to $\mathrm{x}, \mathrm{y}$ and $\mathrm{z}$ chromaticity coordinates. As the three fractions add up to unity, only $\mathrm{x}$ and $\mathrm{y}$ need to be plotted in the orthogonal CIE-1931 chromaticity space to conveniently describe the fluorescence colour of each analyzed fluid inclusion. Data reading was made by Microsoft Excel and Golden Software Surfer 8 softwares.

Confocal laser scanning microscopy (CLSM) was applied to estimate the vapour volume fraction $\left(\varphi_{\text {vap }}\right)$ of $\mathrm{HC} 2$ petroleum inclusions. The confocal images were acquired on an Olympus Fluoview FV1000 Laser Scanning Confocal Microscope (FV1000-Inverted) using a $405 \mathrm{~nm}$ excitation laser source (emission filter 461-561nm, dichroic mirror DM405/488) using an Olympus long working distance 40x objective.

The intense motion of bubbles within the petroleum inclusions due to the excitation laser beam prevents image acquisition at room temperature. Hence, we attached a Linkam THMSG600 heating-freezing stage upside down on the stage of the confocal microscope. Using spacers of appropriate height between the microscope and heating-freezing stage, petroleum inclusions could be scanned without focus limitations within the chip. The confocal images were obtained at the homogenization temperatures of the individual inclusions. During thresholding of the acquired images and the volumetric 3D reconstruction the following procedure was performed. The data area of the optical sectioning was thresholded by half of the maximum intensity of the sample and the volume of the pixels above the limit was counted (using the lateral and vertical resolution of the image acquisition). The volume of the bubbles was calculated using their measured diameters. The diameter of the gas bubbles was determined from photomicrographs, which were taken in transmitted light, focused at the widest (equatorial) section of each bubble at a known temperature. During selection of the petroleum inclusions for CLSM analysis, we attempted to select inclusions with undistorted, spherical bubbles at room temperature. The detailed principles and the original procedures for the acquisition of CLSM images of petroleum inclusions are described in PIRONON et al. (1998).

Microthermometry was carried out using a Linkam THMSG-600 heating-freezing stage mounted on an Olympus BX-41 microscope using long working distance objectives $100 \mathrm{x}$. The stage was calibrated using synthetic fluid inclusions trapped in quartz with an open sample container covered with a silver lid at -56.6 , 0.0 and $374{ }^{\circ} \mathrm{C}$. The accuracy of the measurements was $\pm 0.1{ }^{\circ} \mathrm{C}$ below and $\pm 1{ }^{\circ} \mathrm{C}$ above $0{ }^{\circ} \mathrm{C}$. The homogenization temperature was usually determined only with the cycling method (GOLDSTEIN, 2003). The salinities of the aqueous inclusions are reported in mass $\%$ of $\mathrm{NaCl}$ equivalent following the calculated values of BODNAR (1993). The salinities were calculated from the final ice melting temperatures $\left(T_{\mathrm{m}}(\mathrm{Ice})\right.$. The concentrations of methane in the methane-bearing inclusions are not known, so the possible effects of the dissolved methane and the methane-hydrate-clathrate to the salinity could not be deduced. The salinities of the present study are therefore maximum values (SCHUBERT et al., 2007). Microthermometry data evaluation was followed after BAKKER\& BROWN (2003).

The pressure-temperature $(P-T)$ conditions of the observed equilibrium mineral assemblages can be calculated using the thermodynamic properties of the minerals (HOLLAND \& POWELL, 1998 ) with WinDomino Software (DE CAPITANI \& BROWN, 1987; DE CAPITANI, 1994). WinDomino calculates the minimum Gibbs energy assemblage for a given $P-T$ area in the case of a chemically closed system. These results could be compared to and completed by the estimations of LIOU et al. (1991) for the $P-T$ stability fields of different zeolites, and by temperature data from 
fluid inclusion microthermometric measurements as well as borehole temperature measurements (JORGENSEN, 2006).

The minerals in the present study are abbreviated according to WHITNEY \& EVENS (2010). Vein microtextures are reviewed following the nomenclature of BONS (2000) and OLIVER \& BONS (2001).

In the case of fluid inclusion terminology, those of DIAMOND (2003) and SCHUBERT et al. (2007) were followed. Discussion of the results of fluid inclusion petrography, microthermometry, Raman spectroscopy and UV-fluorescent micro-spectroscopy used the same abbreviations for the notation of fluid inclusion types and assemblages. With regard to the composition of the fluid inclusions, AQ was used for the aqueous and HC for the hydrocarbon-containing fluid inclusions. For genetic types $\mathrm{P}$ for the primary, $\mathrm{S}$ for the secondary and PS for the pseudo-secondary were used. The subsequent assemblages were numbered with Arabic numbers increasing from oldest to youngest ones. For example the earliest primary fluid inclusion assemblage with aqueous composition was noted as AQ_P1. The physical phases of the contents of the fluid inclusions were abbreviated as $\mathrm{L}$ for liquid, $\mathrm{V}$ for vapour and $\mathrm{S}$ for solid phases. A phase change from a liquid plus vapour phase to a single liquid phase could be abbreviated as $\mathrm{L}+\mathrm{V} \rightarrow \mathrm{L}$.

\section{RESULTS}

\subsection{Petrography}

The core samples of Üllés-61 are cross-cut by a dense vein network. The angular grains of the host rock show a brecciated structure and debris of vitrophyric-rimmed lapilli occurs among these rock fragments (Fig. 3/a). The dense fracture network in the rock is partly or completely filled by zeolites. Most of the pore space is filled by transparent or white crystals of analcime. Leucitohedron-shaped crystals in the partially-filled voids can also be observed. On the blocky analcime crystals white, translucent, rhombic or coffin-shaped prisms of heulandite crystals could be seen. Tiny needles appear as solid inclusions within the main fracturefilling analcime and heulandite crystals, which were identified as mesolite by Raman spectroscopy (Fig. 3/b, 3/c). The mesolite crystals are sporadically displayed in the analcime while in the heulandite it occurs more massively as radial aggregates (Fig. 3/d). Milky-white stilbite also occurs infrequently on the heulandite crystals. The sequence of the fracture-filling zeolites in these Analcime-type (Anl-type) veins is as follows: early Mes $\rightarrow$ Anl $\rightarrow$ late $\mathrm{Mes} \rightarrow \mathrm{Heu} \rightarrow \mathrm{Stb}$ (Table 1). The growth direction of the crystals extends from the vein walls towards the centre of the

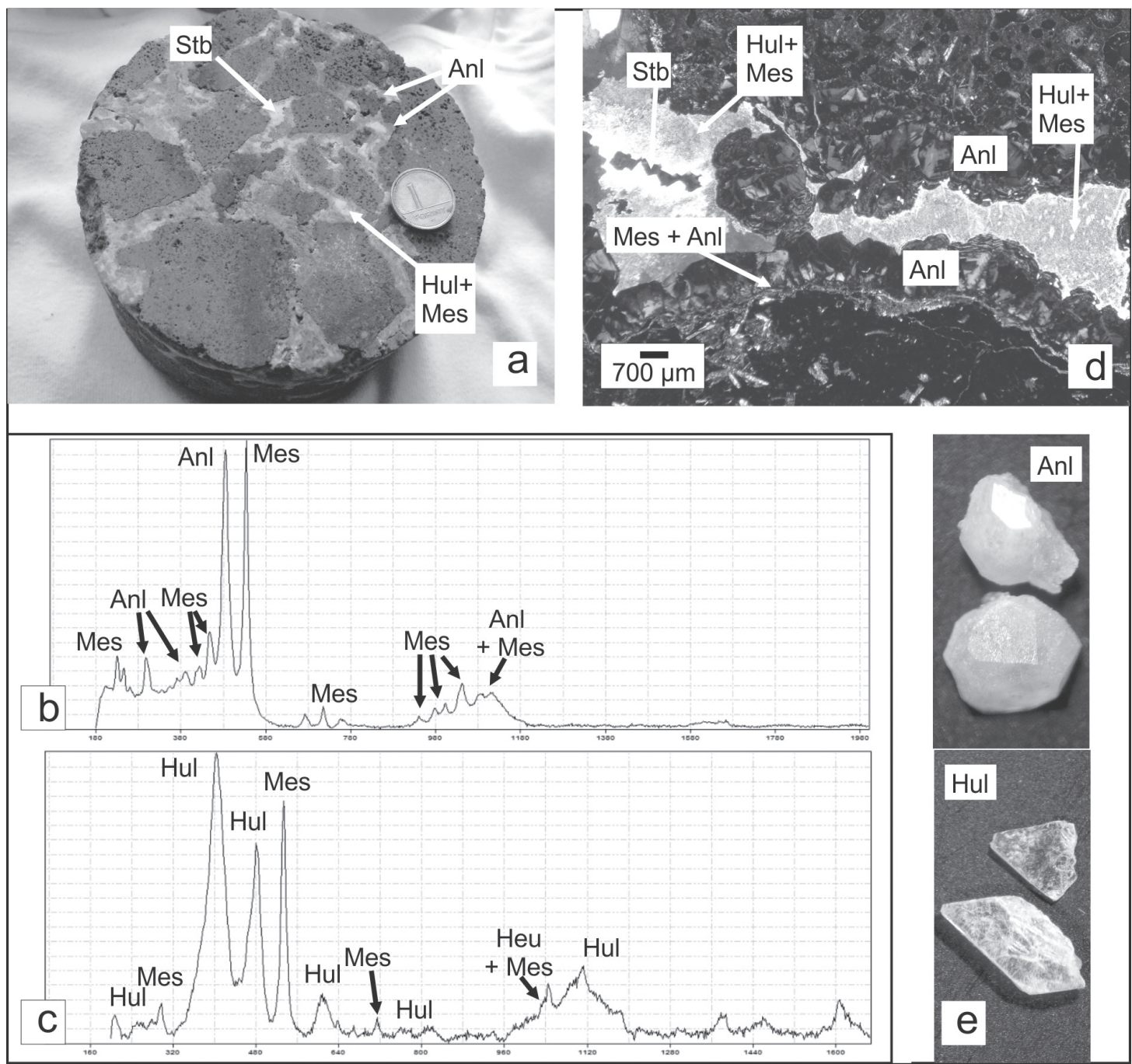

Figure 3. a) The dense vein network is cemented by analcime, mesolite, heulandite and stilbite in a core sample from the Üllés- 61 well.The veins in the basaltic rock are partly open in places. The diameter of the coin is $10 \mathrm{~mm}$. b) and c) The mesolite fibres in analcime (2b) and heulandite (2c) were detected by Raman spectroscopy. d) TheAnl-type vein shows a syntaxial vein structure, the analcime, mesolite and stilbite crystals point to the centre of the vein. The vein is partly open at the top of the stilbite crystals. e) The leucitohedron-shaped analcime crystals and coffin-shaped heulandite crystals from cuttings from the Üllés-65/A well. The diameter of the crystals are about half a millimetre. 
veins, so the vein structure could be considered as syntaxial, according to BONS (2000) (Table 1, Fig. 3/d).

Petrographic and Raman spectroscopy studies on samples from the Üllés-65/A well revealed narrow (1-2 mm wide) veins filled with analcime. Although not as vein-filling, but as small pieces in the cuttings, we identified euhedral crystals: coffin- or rhombic-shaped heulandite crystals and leucitohedron-shaped analcime crystals (Fig. 3/e). Trace amounts of fibre-shaped laumontite crystals also appeared in the cuttings of the Üllés-65/A well.

\subsection{WinDomino modeling}

The pressure-temperature $(P-T)$ conditions of the observed equilibrium mineral assemblages can be calculated by WinDomino software, but it is only possible in a closed chemical system. So the $P-T$ stability fields of the Na-zeolites (analcime) and Ca-zeolites (heulandite-stilbite) could be modeled separately. There are no thermodynamic data available for mesolite, because it is a mixed Na-Ca zeolite, so it could not be put in any of the models.

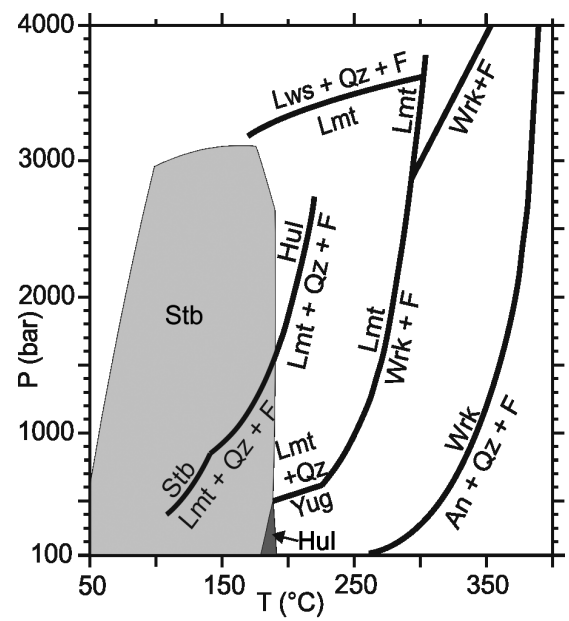

Figure 4. The calculated equilibrium $P$-T ranges for heulandite (dark grey area) and stilbite (light grey area) by WinDomino with the zeolite stability zones (marked by the lines) of LIOU et al. (1991). The stability zone of heulandite is partly similar in temperature but totally different in pressure in the WinDomino calculations and in the calculations of LIOU et al. (1991). The stability zone of stilbite is partly similar in temperature, but WinDomino calculated a wider temperature dimension for stability at lower pressures than LIOU et al. (1991).
Analcime is stable in a very wide range of temperature and pressure conditions compared to heulandite and stilbite. The stability field of heulandite extends between 180 and $190{ }^{\circ} \mathrm{C}$ and below 500 bar. Stilbite is stable below $180-190{ }^{\circ} \mathrm{C}$, but its stability is not really dependent on pressure as it is stable from $100 \mathrm{bar}-3 \mathrm{kbar}$.

The equilibrium pressure-temperature zones of WinDomino could be compared with the zeolite stability zones shown on the Figure 1 in LIOU et al. (1991) (Fig. 4). The diagram in LIOU et al. (1991) shows that heulandite is stable between 140 and $220^{\circ} \mathrm{C}$ and over a wide pressure range, from 850 - 2750 bar, while stilbite is stable below $140{ }^{\circ} \mathrm{C}$ and below 850 bar.

The calculated equilibrium temperature ranges of the minerals are in agreement with their given temperature ranges by LIOU et al. (1991) suggests a decreasing temperature trend during fracture cementation (Fig. 4). For pressure an unequivocal trend could not be given.

\subsection{Fluid-inclusion petrography and microthermometry}

During the fluid inclusion petrographic studies the criteria of Goldstein (2003) were followed to classify fluid inclusion assemblages. In the Anl-type veins, analcime contains measureable aqueous inclusions and analcime and heulandite contain measureable HC-containing fluid inclusions (Fig. 5/a). In the mesolite fibre-shaped crystals no fluid inclusions suitable for microthermometry were discovered.

Early and late primary (P) aqueous (AQ) fluid inclusion assemblages could be distinguished (AQ_P1 and AQ_P2) in analcime, trapped along growth zones. These assemblages straddle pseudo-secondary (PS) aqueous fluid inclusions trapped along healed fractures in the crystals (AQ_PS). The aqueous inclusions have irregular shapes with a maximum dimension of $12 \mu \mathrm{m}$ (AQ P1) and $66 \mu \mathrm{m}(\mathrm{AQ} P 2)$, respectively (Table 3). The estimated $\varphi_{\text {vap }}$ values at room temperature are constant within the individual inclusion assemblages.

Based on the UV fluorescence colours, two different types of hydrocarbon ( $\mathrm{HCl}$ and $\mathrm{HC} 2$ )-containing inclusion assemblages were trapped within the analcime crystals along subsequent growth zones as described by SZABÓ et al. (2012). The very infrequent primary, two-phase $\mathrm{HCl}$ _P inclusions have a very light brown colour in normal transmitted light, and an intense yellow fluorescence colour under UV excitation. The small groups of
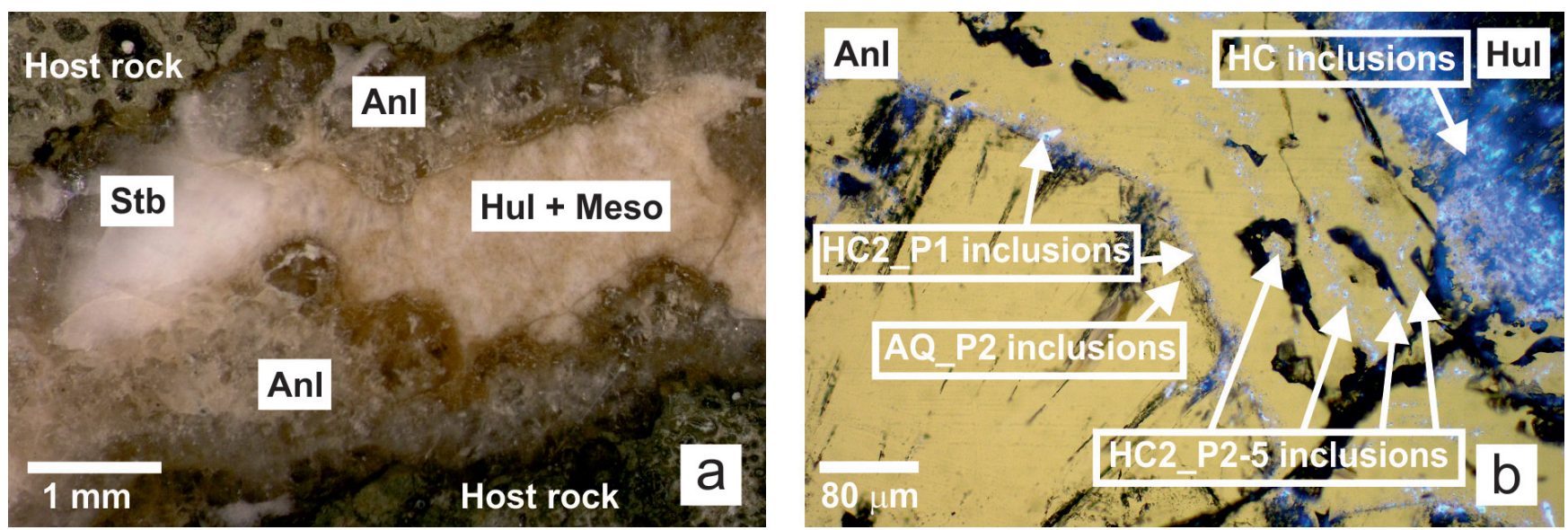

Figure 5. a) A reflected light photograph of a cemented multiphase fracture in basalt as host rock. The analcime and heulandite crystals are darker in places where they contain petroleum inclusions (Üllés-61 well). b) The primary aqueous (AQ P2) and HC2-containing (HC2 P1, HC2 P2, HC2 P5) inclusions in analcime and HC-containing inclusions in heulandite in an Üllés-61 sample cut under ultraviolet excitation and normal light. The AQ_P2 and HC2_P1 inclusion assemblages are captured in the same growth zone - before the other HC2 inclusion generations (HC2 P2-P5) - therefore they are co-genetic with each other. The heulandite contains many HC-bearing inclusions without any recognizable growth zone. 

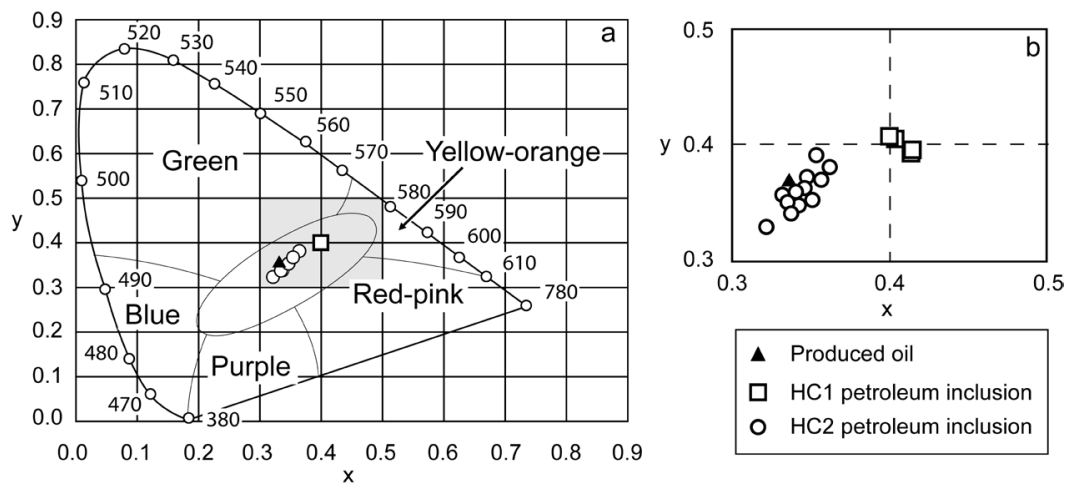

Figure 6. a) Ultraviolet-fluorescence colours of $4 \mathrm{HC} 1$ and $11 \mathrm{HC} 2$ petroleum inclusions as well as the produced oil sample, plotted in the CIE-1931 chromaticity diagram. b) Inset marked with grey box in Fig. 5a. It is obvious that the fluorescent properties of $\mathrm{HC} 1$ and $\mathrm{HC} 2$ petroleum inclusions differ significantly, while the fluorescence of the produced oil is practically identical with the late $\mathrm{HC2}$ petroleum.

these $\mathrm{HCl}$-containing inclusions were trapped prior to the HC2containing inclusions (early type). The late type, HC2-containing, primary two-phase HC2_P inclusions are colourless in normal transmitted light and show a visually intense green fluorescence colour (Fig. 5/b). Large quantities of these inclusions could be observed along several successive growth zones. At least five zones could be distinguished in samples of the Üllés-61 well (HC2_P1-HC2_P5) (Fig. 5/b). The HC1_P inclusions were trapped after the AQ_P1 early aqueous inclusions, but prior to the AQ_P2 late aqueous inclusions. The earliest HC2_P inclusions are trapped in the growth zone of AQ P2 inclusions parallel to the aqueous inclusions (Fig. 5/b). In some cases three-phase, oil-bearing aqueous inclusions occur in the zone of AQ_P2 and $\mathrm{HC} 2 \mathrm{P}$, which proves that the earliest zone of the $\mathrm{HC} 2$ inclusions $\left(\mathrm{HC}_{2} \mathrm{P} 1\right)$ are co-genetic with the AQ P2 inclusions. After the joint zone of AQ_P2 and HC2 P inclusions we found many zones of HC2 P inclusions (HC2 $\mathrm{P} 2, \mathrm{HC} 2$ P3...etc.). The shapes of $\mathrm{HC} 2$ inclusions are more rounded than the aqueous inclusions, and their maximum dimension is $20 \mu \mathrm{m}$ in samples of the Üllés-61 well and $78 \mu \mathrm{m}$ in samples of the Üllés-65/A well. The volume fractions of the vapour phase $\left(\varphi_{\text {vap }}\right)$ in the HC2 inclusions are mostly uniform at room temperature. In addition, secondary HC2-containing (HC2 S) inclusions could be observed along healed fractures in analcime.

Both $\mathrm{HC} 1$ and $\mathrm{HC} 2$ petroleum inclusions were analyzed under UV excitation and their fluorescence responses were detected in the visible-near infrared range ( $400-880 \mathrm{~nm})$. A minute quantity of the produced petroleum fluid was also analyzed using an identical instrumental setup. The transformed spectra were converted into the CIE-1931 chromaticity coordinates. Each datum point represents one representative spectrum of a petroleum inclusion. In the CIE diagram the petroleum types ( $\mathrm{HC} 1, \mathrm{HC} 2$, produced oil) are arranged in two separate groups (Fig. 6). The fluorescence properties of the $\mathrm{HCl}$ and $\mathrm{HC} 2$ petroleum inclusions are located on different segments of the maturity curve (Fig. 6), namely, the $\mathrm{HC} 2$ fluid is blue-shifted relative to the $\mathrm{HCl}$ petroleum. The fluorescence datum point of the produced oil overlaps the points of $\mathrm{HC} 2$ (Fig. 6).

Results of microthermometric measurements are provided in Table 3. Inclusions of the primary aqueous inclusion assemblages undergo homogenization to liquid $\left(\mathrm{L}_{\mathrm{AQ}}+\mathrm{V} \rightarrow \mathrm{L}_{\mathrm{AQ}}\right)$ at 124 to $145^{\circ} \mathrm{C}$ (AQ_P1 inclusions), 129 to $149^{\circ} \mathrm{C}$ (in Üllés-61) and 131 to $142{ }^{\circ} \mathrm{C}$ (in Üllés-65A) (both AQ_P2). The pseudo-secondary aqueous $\mathrm{AQ}$ PS inclusions homogenize into the liquid phase $\left(\mathrm{L}_{\mathrm{AQ}}+\mathrm{V} \rightarrow \mathrm{L}_{\mathrm{AQ}}\right)$, and the homogenization temperatures are similar to the primary inclusions, between $124-132{ }^{\circ} \mathrm{C}$. Based on the $T_{\mathrm{m}}$ (Ice) value of -0.3 and $-0.4{ }^{\circ} \mathrm{C}$, the salinity of the AQ_P2 inclusions is ca. $0.53-0.71$ mass $\%$ in $\mathrm{NaCl}$ equivalent (BODNAR, 1993). There are no $T_{\mathrm{m}}$ (Ice) values and salinity data for AQ P1 inclusions because the small inclusions were not measureable.

The $T_{\mathrm{h}}$ of HC1_P inclusions were very hard to measure, since inclusions generally decrepitated before the homogenization. However, one successful measurement yielded a $T_{\mathrm{h}}$ of $121.5 \pm 1{ }^{\circ} \mathrm{C}$. The HC2_P inclusions were trapped along (at least) five different growth zones in Üllés-61, but their homogenization temperatures do not show any appreciable temperature variance (Table 3). The

Table 3. Microthermometric results in the Anl-type veins.

\begin{tabular}{|c|c|c|c|c|c|c|c|}
\hline $\begin{array}{l}\text { Sample, enclosing } \\
\text { mineral }\end{array}$ & Fluid inclusion type & $\begin{array}{l}\text { Fluid inclusion size } \\
\text { range }(\mu \mathrm{m})\end{array}$ & $T_{\mathrm{h}}\left({ }^{\circ} \mathrm{C}\right)$ & $\begin{array}{l}\text { Number of } \\
\text { measurements }\end{array}$ & $T_{\mathrm{m}}$ Ice $\left({ }^{\circ} \mathrm{C}\right)$ & Salinity (m/m\%) & $\begin{array}{l}\text { Number of } \\
\text { measurements }\end{array}$ \\
\hline & AQ_P1 & $2-12$ & $124-145$ & 44 & - & - & - \\
\hline \multirow[t]{2}{*}{ Ü-61, analcime } & AQ_PS & $4-20$ & $124-132$ & 16 & - & - & - \\
\hline & AQ_P2 & $6-28$ & $129-149$ & 39 & $(-0.3)-(-0.4)$ & $0.53-0.71$ & 11 \\
\hline \multirow[t]{4}{*}{ Ü-65/A, analcime } & AQ_P2 & $3-66$ & $131-142$ & 45 & $(-0.3)$ & 0.53 & 2 \\
\hline & $\mathrm{HC1}$ _P & 40 & 121.5 & 1 & - & - & - \\
\hline & HC2_P1 & $4-8$ & $113-118$ & 35 & - & - & - \\
\hline & HC2_P2 & $3-10$ & $110-121$ & 12 & - & - & - \\
\hline \multirow[t]{4}{*}{ Ü-61, analcime } & HC2_P3 & $3-20$ & $110-121$ & 9 & - & - & - \\
\hline & HC2_P4 & $5-11$ & $116-123$ & 5 & - & - & - \\
\hline & HC2_P5 & $6-13$ & $111-120$ & 5 & - & - & - \\
\hline & $\mathrm{HC} 2 \mathrm{~S}$ & $5-10$ & $113-125$ & 4 & - & - & - \\
\hline Ü-65/A, analcime & $\mathrm{HC2}$ - $\mathrm{P}$ & $3-78$ & $108-118$ & 23 & - & - & - \\
\hline Ü-61, heulandite & $\mathrm{HC2}$ _P & $8-10$ & $121-134$ & 5 & - & - & - \\
\hline
\end{tabular}



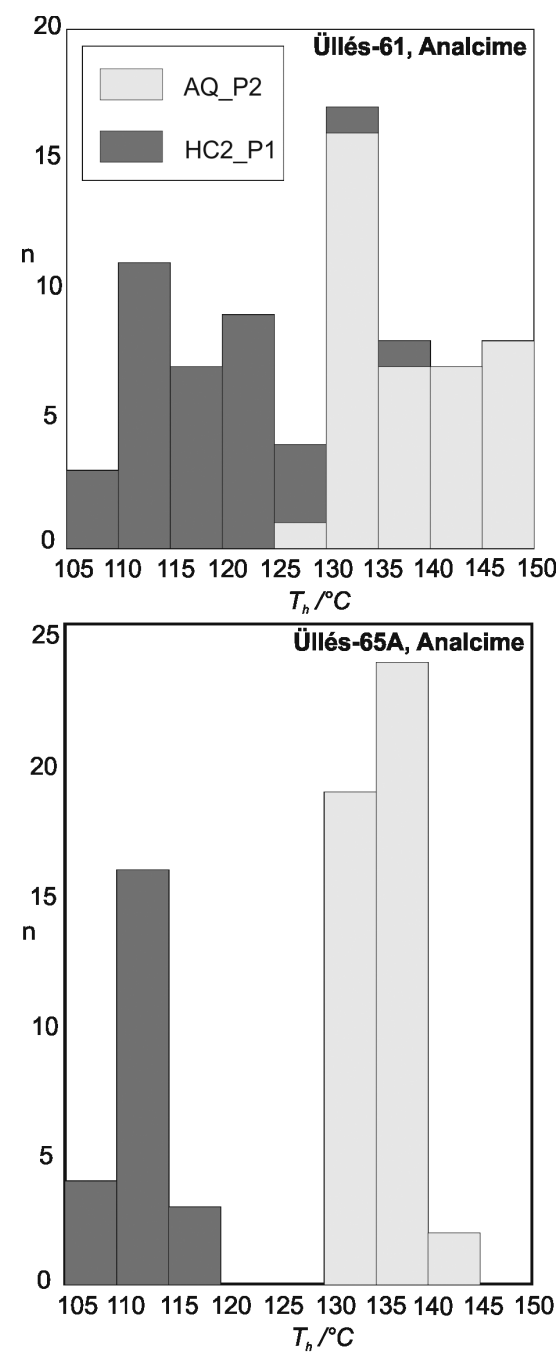

Figure 7. Homogenization temperature distributions of $A Q \_P 2$ and $H C 2$ P 1 inclusions in vein-filling analcime from the Üllés-61 and in Üllés-65/A samples are presented.

homogenization always occurs into the liquid phase, and the temperature ranges $\left(T_{\mathrm{h}}\right)$ are as follows for the subsequent zones of $\mathrm{HC}$ inclusions: HC2_P1: $108-136^{\circ} \mathrm{C}, \mathrm{HC} 2$ P2: $110-125^{\circ} \mathrm{C}, \mathrm{HC} 2$ P3: $110-126{ }^{\circ} \mathrm{C}, \mathrm{HC} 2$ P $4: 114-123{ }^{\circ} \mathrm{C}, \mathrm{HC} 2$ P 5: $111-120^{\circ} \mathrm{C}$ in Ü1lés-61. The primary $\mathrm{HC} 2$ inclusions (co-genetic with the aqueous inclusions) homogenize between $108-118^{\circ} \mathrm{C}$ in Üllés-65A. The $T_{\mathrm{h}}$ distributions of AQ_P2 and $\mathrm{HC} 2$ P1 inclusions in analcime from Ü-61 and Ü-65/A wells are provided in Fig. 7. The AQ_P2 and HC2_P1 inclusions have more similar $T_{\mathrm{h}}$ in samples of the Üllés-61 well than the AQ P2 and $\mathrm{HC} 2$ inclusions in samples from the Üllés-65/A well (with a similar number of measurements). Heulandite also contains two-phase aqueous and HC-containing inclusions, but the genetics of the inclusions could not be clarified in most cases because the mesolite fibres were grown together with heulandite lamellae. There are just a few successful microthermometric measurements in heulandite, because the fluid inclusions decrepitated very easily in the crystals, which have a perfect cleavage parallel to the plane of symmetry. The presumably primary, HC-containing inclusions are rounded with a maximum dimension of $10 \mu \mathrm{m}$. They have no colour in normal transmitted light, and have intense blue fluorescence under UV excitation. Based on these characteristics we suggest calling them HC2 P inclusions. These inclusion assemblages undergo homogenization to a liquid phase from 121 to $133{ }^{\circ} \mathrm{C}$ measured in the Üllés-61 samples.

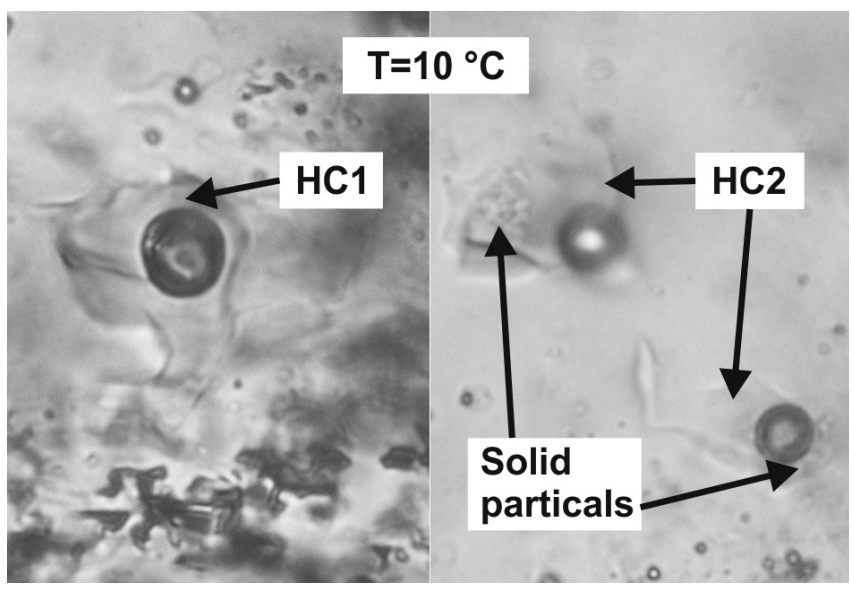

Figure 8. HC2-containing inclusions in analcime have solid-phase particles in the liquid phase at low temperatures after a cooling procedure, while $\mathrm{HC} 1$-containing inclusions remain in the two-phase domain $(\mathrm{L}+\mathrm{V})$ after the cooling and reheating to $10^{\circ} \mathrm{C}$ (Üllés-61 well).

The type and the density of the trapped oil can be estimated from microscopic observations at low temperatures (GRIMMER et al., 2003). Observing the inclusions, both the HC1- and the $\mathrm{HC} 2$-containing inclusions are in the two-phase domain at room temperature, and they homogenize into the liquid phase. Cooling the samples down to $-120^{\circ} \mathrm{C}$ none of them transformed into three phases $\left(\mathrm{L}+\mathrm{V} \rightarrow \mathrm{L}_{1}+\mathrm{L}_{2}+\mathrm{V}\right)$ and the homogenization temperatures were not around $+52{ }^{\circ} \mathrm{C}$, which excludes the trapping of condensate fluid in the samples. Below $20^{\circ} \mathrm{C}, \mathrm{HC} 2$-containing inclusions have a solid phase (presumably wax) in the liquid phase, and while heating the cooled sample, the slight motion of these particles could be observed with changing shape of the vapour bubble. HCl-containing inclusions do not show any of these reactions at low temperatures. According to GRIMMER et al. (2003), HC1containing inclusions show the behavior of inclusions containing black oil, and HC2-containing inclusions are commensurate with those containing light oil (Fig. 8).

\subsection{The Raman micro-spectrometry of fluid inclusions}

In the Anl-type veins, the composition of the primary and secondary aqueous inclusions trapped in analcime were determined by Raman spectroscopy. Qualitatively, these inclusions contain methane in the vapour phase at room temperature. The soundproof measurements - necessary for quantitative composition determinations - were disturbed by the presence of water captured in the structure of the analcime, due to the overlap of Raman peaks of inclusion water and those of structural water (Fig. 9). Gas-hydrate (methane clathrate) formation and melting could not be observed and measured by Raman micro-spectroscopy, so the accurate salinity of the aqueous inclusions and therefore the composition of the inclusions could not be given exactly.

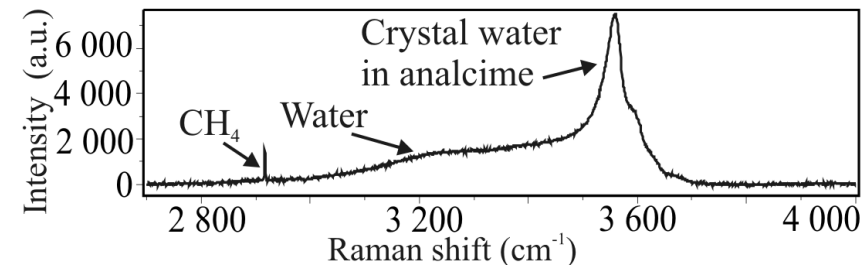

Figure 9. The Raman spectrum of an AQ_P2 inclusion captured targeting the vapour phase from a vein-filling analcime sample at room temperature (Üllés-65A) shows the peak of methane in the vapour phase $\left(2916 \mathrm{~cm}^{-1}\right)$ and the sign of liquid water with the peak of the crystal water of analcime $\left(3557 \mathrm{~cm}^{-1}\right)$. 


\subsection{UV fluorescent micro-spectrometry}

In case of the HC-containing inclusions and the crude oil, two parameters were calculated. The $\lambda_{\max }$ (the wavelength of the excitation with the maximum intensity) and the $Q$ value $(Q=R / G$ quotient, which is the ratio of the intensities belonging to emission wavelengths at $650 \mathrm{~nm}$ and $500 \mathrm{~nm}$, respectively) according to STASIUK \& SNOWDON (1997). The representative values of $\lambda_{\max }$ and Q quotient are listed in Table 4. In HC1-containing inclusions the micro-fluorescent parameters are $\lambda_{\max }=585 \mathrm{~nm}$ and $\mathrm{Q}=0.94$. In contrary to these values, in HC2-containg inclusions $\lambda_{\max }=547-556 \mathrm{~nm}$ and $\mathrm{Q}=0.59-0.74$ are typical. The parameters of the crude oil are similar to the $\lambda_{\max }$ and $\mathrm{Q}$ values of HC2-containing inclusions, but they are both a little bit lower, being $\lambda_{\max }=548 \mathrm{~nm}$ and $\mathrm{Q}=0.55$. The fluorescent properties of the measured HC fluid inclusions display a systematic blue shift towards shorter wavelengths during the $\mathrm{HC}$ migration and trapping.

Table 4. The UV fluorescent parameters of HC fluids trapped in fluid inclusions and the crude oil.

\begin{tabular}{lcccc}
\hline HC samples & $\lambda_{\max }$ & $\mathrm{Q}$ & $\mathrm{I}_{\lambda=500 \mathrm{~nm}}$ & $\mathrm{I}_{\lambda=650 \mathrm{~nm}}$ \\
\hline $\mathrm{HC} 1$ & 585 & 0.94 & 138 & 129 \\
$\mathrm{HC2}$ 1 & 556 & 0.74 & 182 & 135 \\
$\mathrm{HC2} 22$ & 553 & 0.61 & 173 & 105 \\
$\mathrm{HC2} 33$ & 547 & 0.59 & 179 & 106 \\
$\mathrm{HC2} 4$ & 549 & 0.63 & 187 & 119 \\
$\mathrm{HC2} 5$ & 549 & 0.66 & 161 & 107 \\
Crude oil & 548 & 0.55 & 196 & 107 \\
\hline
\end{tabular}

UV-fluorescence micro-spectroscopy confirms that the two different $\mathrm{HC}$ inclusion assemblages trapped different oil types, and indicates that the crude oil produced in the field is more similar to the oil trapped in the later formed HC2 fluid inclusion assemblage. API gravities estimated from fluorescence colour are $30-35^{\circ}$ for $\mathrm{HCl}$ and $40-45^{\circ}$ for $\mathrm{HC} 2$ when following the approach outlined in BODNAR (1990) (SZABÓ et al., 2012).

\subsection{Confocal laser scanning microscopy (CLSM)}

The CLSM analyses were performed on petroleum inclusions trapped in analcime. The volume of a representative inclusion above the homogenization temperature and the volume of the vapour phase at $43^{\circ} \mathrm{C}$ were $52.24 \mu \mathrm{m}^{3}$ and $4.75 \mu \mathrm{m}^{3}$, respectively. Hence, the volume fraction $\left(\varphi_{\text {vap }}=V_{\text {vap }} /\left(V_{\text {vap }}+V_{\text {liq }}\right)\right)$ of the vapour phase at $43{ }^{\circ} \mathrm{C}$ is 0.091 . As currently, calibrated thresholding procedures on precise volume estimation in minerals are unavailable, we have performed further calculations using over- and underestimated volume ratios of $10 \%$. The applied volume ratios are summarized in Table 5.

Table 5. Measured volume ratios, estimated trapping temperatures and pressures as well as the calculated GOR and API gravity values for a petroleum inclusion trapped in analcime (Üllés-61 well).

\begin{tabular}{lcccc}
\hline QVAP @ 43 ${ }^{\circ} \mathrm{C}$ (vol\%) & $T_{\mathrm{t}}\left({ }^{\circ} \mathrm{C}\right)$ & $P_{\mathrm{t}}$ (bar) & $\begin{array}{c}\mathrm{GOR} \\
\text { (calculated) }\end{array}$ & $\begin{array}{c}{ }^{\circ} \mathrm{API} \\
\text { (calculated) }\end{array}$ \\
\hline 0.091 (measured by CLSM) & 130 & 152.7 & 76.12 & 37.30 \\
$0.082(-10 \%)$ & 130 & 145.64 & 64.94 & 36.86 \\
$0.10(+10 \%)$ & 130 & 157.32 & 81.57 & 38.98 \\
\hline
\end{tabular}

\subsection{Palaeopressure calculations}

In order to estimate the pressure conditions during filling of the Üllés reservoir, model petroleum compositions were reconstructed using the FIT-Oil software (THIÉRY et al., 2002). For

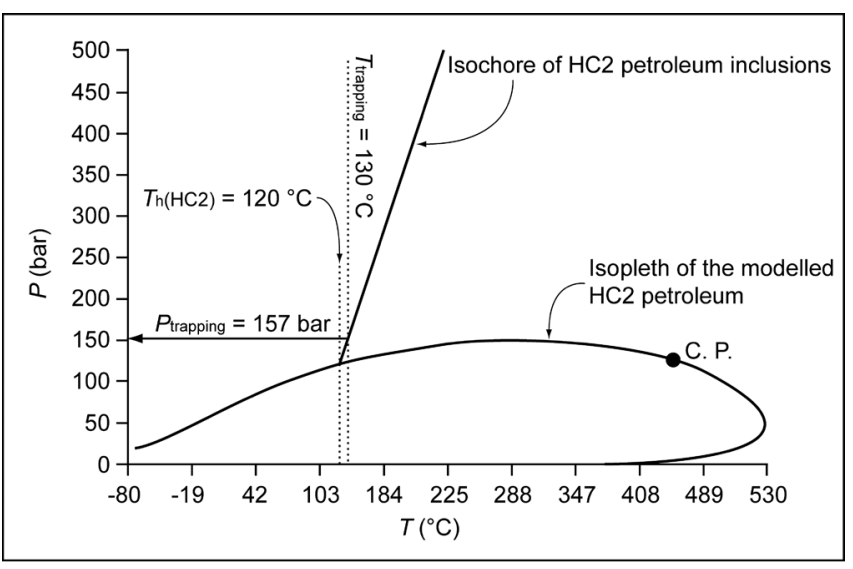

Figure 10. Phase diagram of the fluid trapped in $\mathrm{HC} 2$ petroleum inclusions with the relevant isochore. The calculated trapping temperature and pressure of the $\mathrm{HC} 2$-bearing fluid inclusion generation are marked on the diagram.

the modeling procedure of the trapped petroleum fluid, microthermometric $\left(T_{\mathrm{h}}\right.$ of the selected petroleum inclusion; $\left.120^{\circ} \mathrm{C}\right)$ and its volumetric data (the volume fraction of the vapour phase of 0.091 at $43{ }^{\circ} \mathrm{C}$ ) were used. In order to control the effects resulting in possible inaccuracy of the phase ratio estimation on pressure estimation, compositional modeling was also performed using the over- and underestimated volume ratios.

Additionally, the raw fluid model composition has been refined using typical petroleum fluids of known composition $(\alpha-\beta)$ values of the FIT-Oil software (MONTEL, 1993). The software calculates isopleths and isochores based on the Peng-Robinson equation of state (PENG \& ROBINSON, 1976). In order to validate the computational procedures, we have compared a physical property (API gravity) of the modeled petroleum and produced crude oil using the approach of BODNAR (1990).

To obtain the trapping pressure, the intersection of the isochore of the modeled petroleum fluid with the trapping temperature has to be located in a P-T space (THIÉRY et al. (2002) and references therein) (Fig. 10). As mentioned above, the earliest zone of the $\mathrm{HC} 2$ inclusions ( $\mathrm{HC} 2$ - 1 1) is probably co-genetic with the AQ_P2 inclusions. MUNZ (2001) suggests that if textural criteria indicate co-genetic trapping of petroleum and aqueous inclusions, methane saturation of the aqueous inclusions can be assumed, and the aqueous homogenisation temperature represents the trapping temperature for both types of inclusions. Inclusions of the (AQ_P2) primary aqueous inclusion assemblages undergo homogenization to liquid $\left(\mathrm{L}_{\mathrm{AQ}}+\mathrm{V} \rightarrow \mathrm{L}_{\mathrm{AQ}}\right)$ at 129 to $149^{\circ} \mathrm{C}$ (in Üllés-61) and at 131 to $142{ }^{\circ} \mathrm{C}$ (in Üllés-65A), so these temperature intervals could be given as trapping temperatures. The minimum value of this interval was chosen for modeling: $T_{\text {trapping }}$ $=130^{\circ} \mathrm{C}$. In order to get the trapping pressure, the isochore of the modeled petroleum fluid was intersected by the line representing the trapping temperature $\left(T_{\mathrm{h}, \min }\left(\mathrm{AQ} \_\mathrm{P} 2\right)=T_{\text {trapping }}=130{ }^{\circ} \mathrm{C}\right)$ and thus the trapping pressure arises as 153 bar. Applying the overand underestimated volume ratios, the calculated trapping pressures are 157 bar and 146 bar, respectively.

\section{DISCUSSION}

\subsection{Data evaluation}

After clarification of the sequence of fracture-filling minerals (Table 1), the $P-T$ stabilities of all these phases were calculated by the WinDomino modelling system (DE CAPITANI \& BROWN, 1987; DE CAPITANI, 1994). The resulting models 
could be compared to the estimations of LIOU et al. (1991) for the $P$ - $T$ stability fields of different zeolites. The temperature estimations could be completed by the homogenization temperatures from fluid inclusion microthermometric measurements (Table 3). In addition, the sequence of zeolites could be used as an indicator of changing palaeo-temperature conditions, as it was previously reported from different volcanic provinces (COOMBS et al., 1959; NEUHOFF et al., 1997; JORGENSEN, 2006). BARTH-WIRSCHING \& HÖLLER (1989) confirm that in order to compare zeolite zonation patterns, choosing a reference area with similar chemical compositions is crucial. The formation of zeolite zones could be associated with geothermal areas or could be the result of a burial diagenetic alteration of the basaltic wall rock. The zeolite zones in fractured basaltic rocks observed in the Faeroe Islands (JORGENSEN 2006), Iceland (WALKER, 1960; WEISENBERGER \& SELBEKK, 2009), and in East Greenland (NEUHOFF et al., 1997) are as follows: thomsonitechabazite, analcime, mesolite-scolecite, heulandite-stilbite and laumontite from the surface down to greater depths and higher temperatures. The borehole temperature measurements at these fractured and zeolite-cemented volcanic rocks (JORGENSEN, 2006) could also give estimations for the usual precipitation temperature of different zeolites.

In some places chlorite aggregates occur among the late laumontite crystals in Lmt-type veins, but they were not suitable for chlorite thermometry. However, applying thermometry to chlorite crystals in the vesicles, the subsequent chlorite generations (from Chl1 to Chl4) gave an increasing temperature trend from about $140-185^{\circ} \mathrm{C}$ to a maximum of $205-220^{\circ} \mathrm{C}$ using different chlorite thermometers (SZABÓ et al., 2009b). If the chlorites in the vesicles and in the Lmt-type veins were precipitated simultaneously, then the chlorite thermometry data would suggest that laumontite crystallization could occur at temperatures as high as $205-220^{\circ} \mathrm{C}$. This datum, nevertheless, was not strengthened by the vitrinite reflectance data in the local area measured on marl samples from the EMF. The $\mathrm{R}_{0}$ data $(0.53-0.79 \%)$ show the upper border of the mid-mature oil zone with a temperature lower than $160{ }^{\circ} \mathrm{C}$ (SZABÓ et al., 2009a; DOLTON, 2006). So, the subsequent chlorite generations in the vesicles could alternatively be the product of a very early reheating event in the rock mass. Consequently, the peak temperature suggested by chlorite thermometry must be independent of the temperature data from vein-filling zeolite minerals, and the subsequent chlorite generations in the vesicles do not correspond with the chlorite of the Lmt-type veins.

In the successive zeolites of the Anl-type veins, initially the dominant cation was sodium, whereas later calcium gradually became dominant. The aqueous inclusions trapped in the first precipitated analcime (AQ_P1 inclusions) go to homogenization at around $124-145^{\circ} \mathrm{C}$, which could be regarded as the minimum temperature of their trapping (DIAMOND, 2003). Analcime includes some fibre shaped crystals of mesolite trapped before (but never after) the formation of late AQ_P2 inclusion assemblages. Mesolite usually indicates a higher temperature-pressure environment than the analcime (JORGENSON, 2006). This episodic mesolite precipitation could be the sign of small temperature fluctuations and/or chemical changes in the pore fluid at the time of analcime precipitation. Heulandite also contains mesolite fibreaggregates as inclusions in very large quantities. This suggests that mesolite precipitation predated the heulandite, which crystallized on mesolite fibres. The position of heulandite in the zeolite sequence suggests higher pressure and temperature in the fractures at the time of heulandite precipitation, which also is strengthened by WinDomino calculations $\left(140-190^{\circ} \mathrm{C}\right)$ and estimations from LIOU et al. (1991) $\left(140-170{ }^{\circ} \mathrm{C}\right)$. The closing mineral of the sequence is stilbite, which probably crystallized below $140{ }^{\circ} \mathrm{C}$ based on the WinDomino model. The syntaxial microstructure of the Anl-type veins refers to a fluid dominant system in the fractures during the precipitation of the minerals. The trend of temperature changes could not be given unequivocally, but the temperatures of mineral precipitations in this Anl-vein type were presumably lower than the formation temperature of laumontite in the Lmt-type veins $\left(150-225^{\circ} \mathrm{C}\right.$; SZABÓ et al., 2009b).

Based on fluid inclusion petrographic observations, from all of the vein types only the Anl-type contains petroleum inclusions. Using the FIT-Oil software the estimated trapping pressure of petroleum inclusions varies at about 150-160 bar.

\subsection{Subsidence history}

Based on different thermometric data of the subsequent vein types (SZABÓ et al., 2009b), the post-volcanic temperature evolution and the subsidence history of the volcanic rocks could be modelled in the study area (Fig. 11).

Based on all of the textural features of the basalt, and the presence of intercalated marl layers and marl inclusions in the pyroclasts in both the Ruzsa and the Üllés wells, a subaqueous character is suggested for the volcanism (BALÁZS \& NUSSZER, 1987; SZABÓ et al., 2009b), and this involves rapid cooling and intensive metasomatism of the rock. The fractures in the lapilli and in the massive basalt, where the minerals of Kfp-type and Cal-type veins precipitated, were presumably the results of early cooling of the rock shortly after volcanism in the area (SZABÓ et al. (2009b)). The minerals of Kfp-veins precipitated in fractured lapilli before the final consolidation of the volcanic sediment at around $140-155^{\circ} \mathrm{C}$. The calcite of Cal-type veins crystallized in the fractures of basalt, which were previously filled by altered volcanic material. The subsequent chlorite generations in the vesicles - giving an increasing temperature trend from about $140-185^{\circ} \mathrm{C}$ to a maximum of $205-220^{\circ} \mathrm{C}$ (SZABÓ et al., 2009b) - could be the product of a very early reheating event in the rock mass.

After consolidation, the earliest cement phases in some of the Lmt-type veins from prehnite via early laumontite to thomsonite clearly suggest a cooling trend during fracture cementation from around $130-180^{\circ} \mathrm{C}$ down to $50-90^{\circ} \mathrm{C}$. However, the next, late laumontite phase suggests a higher temperature for the late evolution to the temperature of $150-225^{\circ} \mathrm{C}$ on the basis of the temperature stability of laumontite. Most of the Lmt-type veins contain only late laumontite and calcite suggesting that most of the veins opened at this time. This reheating event (from $50-90{ }^{\circ} \mathrm{C}$ up to around $150-225^{\circ} \mathrm{C}$ ) in Lmt-veins could be the result of some post-volcanic reheating effect that worked by circulating hot hydrothermal fluids in the newly opened or re-opened veins. The late calcite cement of the Lmt-type veins does not yield any valuable information about the temperature of precipitation, but contains secondary aqueous inclusions, which give $135-150^{\circ} \mathrm{C}$ as homogenization temperature suggesting a light, late cooling in this type of vein. Vitrinite reflectance data $\left(\mathrm{R}_{0}=0.53-0.79 \%\right)$ in the local area measured on marl samples of EMF show the upper boundary of the mid-mature oil zone with a temperature lower than $160^{\circ} \mathrm{C}$ (SZABÓ et al., 2009a). So the reheating could reach a maximum of $160^{\circ} \mathrm{C}$ in the marl of the local area.

The presumably youngest Anl-type veins only occur over a restricted area, and their vein-filling minerals (Anl, Heu, Stb) indicate about $125-145^{\circ} \mathrm{C}$ as the precipitation temperature without any sharp spatial or temporal trend. The palaeopressure calcula- 


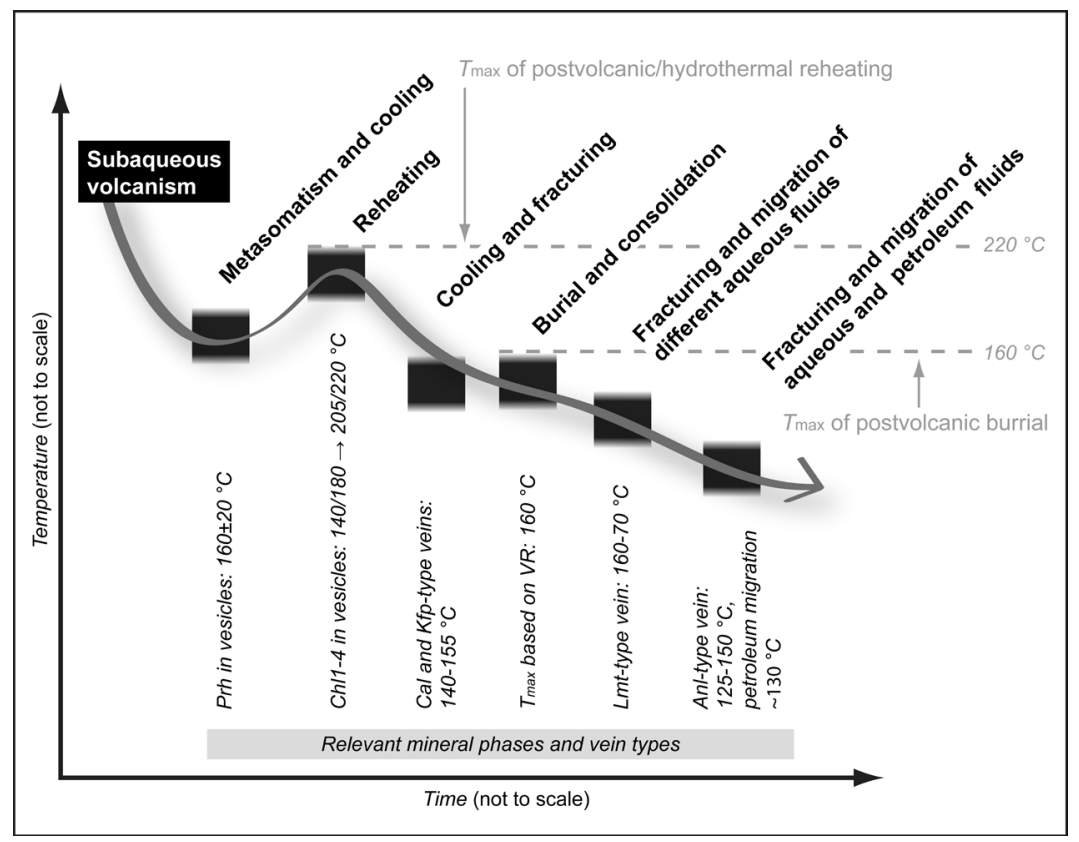

Figure 11. A temperature-subsidence evolution model of the fractured volcano sediment rock body in the Üllés area. The governing events are indicated by boldface type and the applied thermometers by italics.

tions with the trapping temperature of $130^{\circ} \mathrm{C}$ gave $150-160$ bar as estimated for the time of $\mathrm{HC} 2$ petroleum fluid appearance in the fractures of Anl-type. This corresponds to 1500-1600 m maximum subsidence using hydrostatic pressure at the time of hydrocarbon migration. Therefore the trapping of $\mathrm{HC} 2$ fluid occurred at a temperature of $130^{\circ} \mathrm{C}$ and $150-160$ bars, i.e. at 1500 $1600 \mathrm{~m}$ depth. Using the above data, the estimated geothermal gradient seemed to arise ca. $86^{\circ} \mathrm{C} / \mathrm{km}$ during cementation of the Anl-type veins and $\mathrm{HC} 2$ fluid migration. Although at first sight, this value seems to be a strong underestimation of the real trapping pressure,such an elevated geothermal gradient $\left(70^{\circ} \mathrm{C} / \mathrm{km}\right)$ is not uncommon in the Pannonian Basin even recently (SOLEVIC et al., 2006).

The above mentioned, extremely high thermobaric gradient queries the reliability of the applied pressure estimation as well as raising the possibility of alternative scenarios for fracture cementation and fluid migration. The previous results of SZABÓ et al. (2009a) concerning the maturity parameters based on vitrinite reflectance and Rock-Eval pyrolysis measurements suggest that the intercalated marl bodies of the EMF in the local area barely reached the oil window and hence were unable to produce a significant amount of hydrocarbon (oil). It follows that the analcime-hosted HC2 fluid probably did not form in-situ but most probably migrated from adjacent, deeper sub-basin(s) with higher P-T properties and sufficient organic matter.

As shown in Table 4, the spectral parameters of the produced oil and the analcime-hosted HC2 fluid are practically identical. Additionally, SZABÓ et al. (2012) compared the produced oil and the analcime-hosted $\mathrm{HC} 2$ using detailed organic geochemical analyses. They revealed that in terms of the point of maturity and type of source rock the fluids are also extremely similar. Hence, it can be assumed that the HC2 fluid inclusions enclosed a hydrocarbon fluid that is identical in most parameters with the produced oil. Considering that the trapping temperature (ca. $130{ }^{\circ} \mathrm{C}$ ) of the HC2 fluid inclusion assemblages corresponds to that which reigns at their present depth in the reservoir, it could be assumed that the trapping of the HC2 fluid inclusions could be roughly at their recent position. So, the trapping pressure should fall near to the present formation pressure (ca. 250 bar) instead of that suggested by the FIT-Oil modeling (150-160 bar). That is, in the present case this approach is not appropriate to estimate the trapping pressure.

The hypothetical subsidence curve of the rocks was constructed mainly using maximum temperatures obtained from the applied thermometers, however, at least for the youngest vein type; alternative scenarios would also be envisaged. The Anl-type veins only occur over a restricted area and moreover represent an exotic chemical system, namely, sodium as a dominant cation instead of calcium as was usual in the vein system. Additionally, the crosscutting relationship of the Lmt and Anl-type is still unclear. Taking into consideration the afore-mentioned information as well as the fact that the stability field of laumontite is quite extended and includes the formation temperature of the analcime phase as well, it can be presumed that with changing physicochemical conditions (as well as the arrival of petroleum-bearing fluids), the evaluation of the vein system can be explained in a slightly different way too. Since this alternative scenario, the formation and cementation of Anl-type veins might have predated or they could have even formed and cemented coevally with the Lmt-type. The previous scenario is improbable, because there is not any evidence for oil migration during crystallization of Lmt-type veins.

\subsection{The stages and the timing of petroleum migration}

Based on fluid inclusion petrographic observations, from all of the vein types only the Anl-type contains petroleum inclusions, while methane-bearing fluid inclusion assemblages also occur in other vein types. Based on fluorescent parameters, two kinds of petroleum fluids could be distinguished trapped within inclusions. At first yellow-fluorescent petroleum $(\mathrm{HCl})$ was trapped during the precipitation of early growth zones of analcime, which was afterwards followed by the trapping of a petroleum fluid (HC2) with a visually intense green fluorescent colour. The blueshifted nature of the $\mathrm{HC} 2$ fluid relative to the $\mathrm{HC} 1$ petroleum suggest the occurrence of a thermally more mature and/or less degraded fluid (STASIUK \& SNOWDON, 1997) in the pore space 
with time. Considering the fluorescence colours both fluid inclusion oils seem to have a slightly immature character.

Based on the fluorescence parameters, the estimated API gravities are $30-35^{\circ}$ for $\mathrm{HCl}$ and $40-45^{\circ}$ for $\mathrm{HC} 2$ petroleum fluids (SZABÓ et al., 2012), where a lower API gravity (a higher density) usually relates to a lower maturity in the case of the $\mathrm{HCl}$ fluid. The studied crude oil (produced oil) shows very similar fluorescent characteristics to the HC2 fluid trapped in the fluid inclusions (Table 4) suggesting that they are sampled from a very similar fluid migrated in the fracture network and the adjacent vesicular pores of the basaltic host rock.

The slightly immature character of both oils (or the lack of overmature oils) - as presented by the estimated API gravities suggests that at the time of migration and trapping, the fluids were not affected by extreme heating. This means that the oil migration and trapping occurred at lower temperatures than the precipitation of Lmt in Lmt-type veins. The appearance of liquid HC-containing fluids in the pore space would have to have occurred either after cementation of the three early vein types (Kfp-, Cal- and Lmt-type veins) or in the stage of calcite precipitation in Lmt-type veins, but at the time of analcime precipitation in Anl-type veins.

Comparing the microthermometric data from different wells, the AQ P2 and HC2 P1 inclusions have more similar homogenization temperatures in samples from the Üllés-61 well than the AQ_P2 and HC2 inclusions in samples of the Üllés-65/A well with similar number of measurements. This refers to trapping of more gas-saturated liquid in the fractures in the Üllés-61 well than in the Üllés 65/A well (TSENG \& POTTORF, 2002) (Fig. 7).

The slight differences in the fluorescent parameters of the crude oil and the petroleum inclusions suggest geochemical differences in their compositions. The detailed biomarker characterization of the captured inclusion oils and the produced oil could correlate the source rock and the oils, and also could reveal the stages of the migration and accumulation that occurred in the area.

\section{CONCLUSIONS}

The evidence for fracture cementation and fluid evolution that we have presented for the fractured basaltic rocks in the area of Üllés-Ruzsa are based on complex fluid-inclusion analyses and mineral equilibria calculations. This work focused on the zeolite minerals of the Anl-type veins, which occur both as fracture-filling phases in drillcores and as fragments from cuttings. The sequence of the zeolite minerals in Anl-type veins is early Mes $\rightarrow$ $\mathrm{Anl} \rightarrow$ late $\mathrm{Mes} \rightarrow \mathrm{Heu} \rightarrow \mathrm{Stb}$. Based on the equilibrium mineral parageneses at the given stages of the fracture cementation, WinDomino modeling suggests a decreasing temperature trend with time $\left(190{ }^{\circ} \mathrm{C} \rightarrow<140{ }^{\circ} \mathrm{C}\right)$, while no clear trend in pressure could be established with proceeding fracture cementation.

The palaeofluid evolution of the igneous/volcano-sedimentary rock body could be traced using the aqueous and hydrocarbon -bearing fluid inclusion assemblages trapped in the analcime and heulandite grains. Based on fluid inclusion evidence, we have identified three unequivocally distinct fluid migration events, namely, AQ P1 (aqueous) $\rightarrow \mathrm{HC1} \mathrm{P}$ (hydrocarbon) $\rightarrow \mathrm{AQ}$ P2+HC2_P1 (aqueous + hydrocarbon). The occurrence of these fluid inclusions along growth zones as well as formation of threephase $\left(\mathrm{L}_{\mathrm{AQ}}+\mathrm{L}_{\mathrm{HC}}+\mathrm{V}\right)$ fluid inclusions simultaneously with $\mathrm{AQ}$ P2+HC2 P1 fluid inclusion assemblages reveals the above temporal trapping succession of these fluids.

In-situ UV-fluorescence analyses on the analcime-hosted $\mathrm{HC} 1$ and $\mathrm{HC} 2$ hydrocarbon-bearing fluid inclusions as well as on the produced oil of the Üllés-65a well, suggest two major phases can be ascertained. Namely, the significantly more frequent $\mathrm{HC} 2$ petroleum inclusions show characteristic blue-shifted fluorescence properties, i.e. the presence of a more mature fluid relative to $\mathrm{HCl}$. The presence of the $\mathrm{HCl}$ petroleum inclusions along the early growth zones and the supposed lower maturity imply that they probably preserved the remnants of one of the earliest oil migration events in the fracture system.

Alternatively, the UV-fluorescence properties of the $\mathrm{HC} 2$ inclusion oil and the produced oil of the Üllés-65a well are practically identical. Therefore we assume that at least in the area of the Üllés-65a well, the free pore space remains filled (even today), by a hydrocarbon fluid that is reasonably similar to the late $\mathrm{HC} 2$ inclusion oil. As the early Kfp-, Cal-, Lmt-type veins do not contain any traces of hydrocarbon fluid remnants we suppose that the filling of the fractured basalt reservoir is coeval with the fracturing and cementation of the Anl-type veins. Based on microthermometry data of the cogenetic aqueous and hydrocarbon fluid inclusions (AQ_P2 and HC2_P1), the migration of the dominant petroleum-bearing fluid took place at $125-145^{\circ} \mathrm{C}$.

Previous organic geochemical analyses performed on marl samples intercalated with the igneous/volcano-sedimentary rocks as well as on fluid inclusions and produced oil samples revealed that rocks of the Endröd Marl Formation can be most probably regarded as the source rock of both petroleum fluids. However, the low maturity $\left(\mathrm{R}_{0}=0.53-0.79 \%\right)$ of the marl samples in the vicinity of the Anl-type veins suggests that the oil formed in adjacent deeper sub-basins and migrated into the fracture system rather than in-situ maturation of the intercalated marl due to the heat effect of the volcanic rocks. Nevertheless, the reconstructed palaeo-pressure that was characteristic during migration of the $\mathrm{HC} 2$ oil is remarkably high $\left(86^{\circ} \mathrm{C} / \mathrm{km}\right)$ suggesting the reign of an elevated heat flow during this period of basin evolution.

\section{ACKNOWLEDGEMENT}

The authors thank MOL Ltd. for their financial support of the project. Special thanks go to Róbert GYURCSÁNYI (Budapest University of Technology and Ecomics) for his help with UV fluorescent micro-spectroscopy and András SZABÓ (Budapest University of Technology and Ecomics) and Eric Le MENN (University of Nantes) for their help in the Raman micro-spectrometric measurements. The research was supported by Hungarian National Scientific Research Fund (OTKA, K 108375).

\section{REFERENCES}

APLIN, A.C., MACLEOD, G., LARTER, S.R., PEDERSEN, K.S., SORENSEN, H. \& BOOTH, T. (1999): Combined use of Confocal Laser Scanning Microscopy and PVT simulation for estimating the composition and physical properties of petroleum in fuid inclusions.- Mar. Petrol. Geol., 16, 97-110.

BADICS, B., UHRIN, A., VETÖ, I., BARTHA, A. \& SAJGÓ, CS. (2011): Basin-centred gas in the Makó Trough, Hungary: a 3D basin and petroleum system modelling investigation.- Petrol. Geosci., 17, 405-416.

BADICS, B. \& VETÖ, I. (2012): Source rocks and petroleum systems in the Hungarian part of the Pannonian Basin: The potential for shale gas and shale oil plays.- Mar. Petrol. Geol., 31, Issue 1, 53-69.

BAKKER, R.J. \& BROWN, P.E. (2003): Computer modeling in fluid inclusion research.- In: SAMSON, I., ANDERSON, A. \& MARSHALL, D. (eds.): Fluid inculsions - Analysis and interpretation. Mineral Assocication of Canada, $175 \mathrm{p}$.

BALÁZS, E. \& NUSSZER, A. (1987): Magyarország medenceterületeinek kunsági (pannóniai s. str.) emeletbeli vulkanizmusa [Volcanism in the Hungarian basins in the time of Kunsagi (Pannonian .s. str.) - in Hungarian].- A Magyar Állami Földtani Intézet Évkönyve, 69, 95-113.

BART-WIRSCHING, U. \& HÖLLER, H. (1989): Experimental studies on zeolite formation conditions.- Eur. J. Mineral., 1, 498-506.

BODNAR, R.J. (1990): Petroleum migration in the Miocene Monterey Formation, California, USA: constraints from fluid-inclusion studies.- Mineral. Mag., 54, 295-304. 
BODNAR, R.J. (1993): Revised equation and table for determining the freezing point depression of $\mathrm{H}_{2} \mathrm{O}-\mathrm{NaCl}$ solutions.- Geochim. Cosmochim. Ac. (United States), 57,3 p.

BONS, P.D. (2000): The formation of veins and their microstructures.- Journal of the Virtual Explorer, 2.

BOURDET, J., PIRONON, J., LEVRESSE, G. \& TRITLLA, J. (2010): Petroleum accumulation and leakage in a deeply buried carbonate reservoir, Níspero field (Mexico).- Mar. and Petrol. Geol., 27, 126-142.

BURKE, E.A.J. (1994): Raman microspectrometry of fluid inclusions: the daily practice. Fluid Inclusions in Minerals: Methods and Applications.- In: De VIVO, B. \& FREZOTTI, M.L. (eds.): Short Course of the IMA Working Group „Inclusions in Minerals", Virginia Tech (Pontignano - Siena, 1-4 September, 1994).

COOMBS, D.S., ELLIS, A.J., FYFE, W.S. \& TAYLOR, A.M. (1959): The zeolite facies, with comments on the interpretation of geothermal syntheses.- Geochim. Cosmochim. Ac., 17, 53-107.

CSEREPESNÉ, M.B. (1978): A Kiskunhalas-Ny-3. szénhidrogénkutató fúrással feltárt alsó-pannóniai bazalt és proterozoi migmatit képződményekről [The basaltic and proterozooic magmatic rocks of Kiskunhalas-Ny-3 hydrocarbon exploration well - in Hungarian].- Földtani Közlöny, 108/1, 53-64.

DE CAPITANI, C. (1994): Gleichgewichts-Phasendiagramme: Theorie und Software.Beihefte zum European Journal of Mineralogy, 72. Jahrestagung der Deutschen Mineralogischen Gesellschaft, 6, 48.

DE CAPITANI, C. \& BROWN, T.H. (1987): The computation of chemical equilibrium in complex systems containing non-ideal solutions.- Geochim. Cosmochim. Ac., 51, 2639-2652.

DIAMOND, L.W. (2003): Systematics of H2O inclusions.- In: SAMSON I., ANDERSON, A. \& MARSHALL, D. (eds.): "Fluid Inclusions: Analysis and Interpretation" Short Course, Volume 32. Mineralogical Association of Canada, 55-79.

DIAMOND, L.W. (2003): Glossary: Terms and symbols used in fluid inclusion studies.In: SAMSON I., ANDERSON, A. \& MARSHALL, D. (eds.): "Fluid Inclusions: Analysis and Interpretation" Short Course, Volume 32. Mineralogical Association of Canada, 363-372.

DOLTON, G.L. (2006): Pannonian Basin Province, Central Europe (Province 4808) Petroleum Geology, Total Petroleum Systems, and Petroleum Resource Assessment. USGS, Reston, Virginia.

FAROOQUI, M.Y., HOU, H., LI, G., MACHIN, N., NEVILLE, T., PAL, A., SHRIVASTVA, C., WANG, Y., YANG, F.,YIN, C., ZHAO, J., YANG, X. (2009): Evaluating Volcanic Reservoirs.- Oilfield Review, 21/1, 36-47.

GEORGE, S.C., KRIEGER, F.W., EADINGTON, P.J., QUEZADA, R.A., GREENWOOD, P., EISENBERG, L.I., HAMILTON, P.J. \& WILSON, M.A. (1997): Geochemical comparison of oil-bearing fluid inclusions and produced oil from the Toro sandstone, Papua New Guinea.- Org. Geochem., 26, 3-4, 155-173.

GOLDSTEIN, R.H. (2003): Petrographic analysis of fluid inclusions.-Fluid inclusions: Analysis and interpretation, 32, 9-54

GRIMMER, J.O.W., PIRONON, J., TEINTURIER, S. \& MUTTERER, J. (2003): Recognition and differentiation of gas condensates and other oil types using microthermometry of petroleum inclusions (Abstract).- J. Geochem. Explor., 78-79, 367-371.

HAAS, J., BUDAI, T., CSONTOS, L., FODOR, L. \& KONRÁD, GY. (2010): Magyarország pre-kainozoos földtani térképe, 1:500 000.- Magyar Állami Földtani Intézet kiadványa, Budapest.

HOLLAND, T.J. \& POWELL, R. (1998): An internally consistent thermodynamic data set for phases of petrological interest.- J. Metamorph. Geol., 16, 309-343.

JØRGENSEN, Ø. (2006): The regional distribution of zeolites in the basalts of the Faroe Islands and significance of zeolites as paleotemperature indicators.- In: CHALMERS, J.A. \& WAAGSTEIN, R. (eds.): Scientific results from the deepened Lopra-1 borehole, Faroe Islands. Geol. Surv. Den. Greenl., 9, 123-144.

KARLSEN, D.A., NEDKVITNE, T., LARTER, S.R. \& BJØRLYKKE, K. (1993): Hydrocarbon composition of authigenic inclusions: Application to elucidation of petroleum reservoir filling history.- Geochim. Cosmochim. Ac., 57, 15, 3641-3659.

LIOU, J.G., DE CAPITANI, C. \& FREY, M. (1991): Zeolite equilibria in the system $\mathrm{CaAl}_{2} \mathrm{Si}_{2} \mathrm{O}_{8}-\mathrm{NaAlSi}_{3} \mathrm{O}_{8}-\mathrm{SiO}_{2}-\mathrm{H}_{2} \mathrm{O}$. - New Zeal. J. Geol. Geop., 34, 293-301.

MAGOON, L.B. (2004): Petroleum system: nature's distribution system of oil and gas.In: CLEVELAND, C. (ed.): Encyclopedia of Energy, Vol. 4., Elsevier (Academic Press), 823-836.

MAGYAR, I., GEARY, D.H., SÜTÖ-SZENTAI, M., LANTOS, M. \& MÜLLER, P. (1999): Integrated biostratigraphic, magnetostratigraphic and chronostratigraphic correlations of the Late Miocene Lake Pannon deposits.- Acta Geol.Hungarica, 42/1, 5-31

MAGYAR, I., JUHÁSZ, GY., SZUROMINÉ KORECZ, A. \& SÜTŐNÉ SZENTAI, M. (2004): A pannóniai Tótkomlósi Mészmárga Tagozat kifejlődése és kora a Battonya-pusztaföldvári-hátság környezetében [The Tótkomlós Calcareous Marl Member of the Lake Pannon sedimentary sequence in the Battonya-Pusztaföldvár region, SE Hungary - in Hungarian with an English Abstract].- Földtani Közlöny, 134/4, 521-540.

MONTEL, F. (1993): Phase Equilibria needs for petroleum exploration and production industry.- Fluid Phase Equilibr., 84, 343-367.

MUNZ, A.I. (2001): Petroleum inclusions in sedimentary basins: systematic, analytical methods and applications.- Lithos, 55, 195-212.

NEUHOFF, P.S., WATT, W.S., BIRD, D.K. \& PEDERSEN, A.K. (1997): Timing and structural relations of regional zeolite zones in basalts of the East Greenland continental margin.- Geology, 25, 803-806.

OLIVER, N.H.S. \& BONS, P.D. (2001): Mechanisms of fluid-flow and fluid-rock interaction in fossil metamorphic hydrothermal systems inferred from vein-wall rock patterns, geometry and microstructure.- Geofluids, 1, 137-162.

OXTOBY, N. (2002): Comments on: assessing the maturity of oil trapped in fluid inclusions using molecular geochemistry data and visually-determined fluorescence colours.-Appl. Geochem., 17, 1371-1374.

PAP, S. (1983): Alsó-pannóniai bazalt vulkanizmus Balástya és Üllés-Ruzsa-Zákányszék térségében [Lower Pannonian basalt volcanism in the Balástya and Üllés-RuzsaZákányszék areas - in Hungarian].- Földtani Közlöny, 113/2, 163-170.

PENG, D.Y. \& ROBINSON, D.B. (1976): A New Two-Constant Equation of State.- Ind. Eng. Chem. Fundam., 15, 59-64.

PIRONON, J., CANALS, M., DUBESSY, J., WALGENWITZ, F. \& LAPLACE-BUILHE, C. (1998): Volumetric reconstruction of individual oil inclusions by confocal scanning laser microscopy.- Eur. J. Mineral., 10, 1143-1150.

SCHUBERT, F., DIAMOND, L.W. \& M. TÓTH, T. (2007): Fluid-inclusion evidence of petroleum migration through a buried metamorphic dome in the Pannonian Basin, Hungary.- Chem. Geol., 244, 357-381.

SHEPHERD, T.J., RANKIN, A.H. \& ALDERTON, D.H.L. (1985): A Practical Guide to Fluid Inclusion Studies.- Blackie and Son Ltd., 239 p.

SOLEVIC, T., STOJANOVIC, K., JOVANCICEVIC, B., MANDIC, G., SCHWARZBAUER, J. \& VITOROVIC, D. (2006): Multivariate statistical methods applied to interpretation of saturated biomarkers (Velebit oil field, SE Pannonian Basin, Serbia).- J. Serb. Chem. Soc, 71/7, 745-769.

STASIUK, L.D. \& SNOWDON, L.R. (1997): Fluorescence micro-spectrometry of synthetic and natural hydrocarbon fluid inclusions: crude oil chemistry, density and application to petroleum migration.-Appl. Geochem., 12, 229-241.

SZABÓ, B., HETÉNYI, M., SCHUBERT, F., MILOTA, K. \& M. TÓTH, T. (2009a): Repedezett bazaltanyagú szénhidrogén rezervoárok Üllés-Bordány térségében. [Fractured basaltic hydrocarbon reservoirs in Üllés-Bordány area - in Hungarian].- In: M. TÓTH, T. (ed.): Magmás és metamorf képződmények a Tiszai egységben, GeoLitera, $1-9$.

SZABÓ, B., SCHUBERT, F. \& M. TÓTH, T. (2009b): Paleofluid evolution of the fractured basalt hydrocarbon reservoir in the Üllés-Ruzsa-Bordány area, SE Hungary.Central European Geology, 52/3-4, 299-323.

SZABÓ, B., SCHUBERT, F., VOLK, H. \& MANZUR, A. (2012): Fluid inclusion analysis as additional tool for comprehension of petroleum systems: A case study from the Pannonian Basin (Hungary).- AAPG Search and Discovery Article \#40917, AAPG Annual Convention and Exhibition, April 22-25, 2012, Long Beach, California.

THIÉRY, R., PIRONON, J., WALGENWITZ, F. \& MONTEL, F. (2002): Individual characterization of petroleum fluid inclusions (composition and P-T trapping conditions) by microthermometry and confocal laser scanning microscopy: inferences from applied thermodynamics of oils.- Mar. Petrol. Geol., 19, 847-859.

WALKER, G.P.L. (1960): Zeolite zones and dike distribution in relation to the structure of the basalts of eastern Iceland.- J. Geol., 68, 515-528.

WEISENBERGER, T. \& SELBEKK, R.S. (2009): Multi-stage zeolite facies mineralization in the Hvalfjördur area, Iceland.- Int. J. Earth Sci., 98, 985-999.

WHITNEY, D.L. \& EVANS, B.W. (2010): Abbreviations for names of rock-forming minerals.-Am. Mineral., 95, 185-187.

WYSZECKI, G. \& STILES, W.S. (2000): Color science: concepts and methods, quantitative data and formulae.- John Wiley and Sons, 2nd Edition, 156 p. 